\title{
Serotonin, But Not $N$-Methyltryptamines, Activates the Serotonin 2A Receptor Via a $\beta$-Arrestin2/Src/Akt Signaling Complex In Vivo
}

\author{
Cullen L. Schmid ${ }^{1,2}$ and Laura M. Bohn ${ }^{1}$ \\ ${ }^{1}$ The Scripps Research Institute, Molecular Therapeutics and Neuroscience, Jupiter, Florida 33458, and ${ }^{2}$ The Ohio State University Neuroscience Graduate \\ Studies Program, Columbus, Ohio 43210
}

\begin{abstract}
Hallucinogens mediate many of their psychoactive effects by activating serotonin $2 \mathrm{~A}$ receptors $\left(5-\mathrm{HT}_{2 \mathrm{~A}} \mathrm{R}\right)$. Although serotonin is the cognate endogenous neurotransmitter and is not considered hallucinogenic, metabolites of serotonin also have high affinity at 5- $\mathrm{HT}_{2 \mathrm{~A}} \mathrm{R}$ and can induce hallucinations in humans. Here we report that serotonin differs from the psychoactive $N$-methyltryptamines by its ability to engage a $\beta$-arrestin2-mediated signaling cascade in the frontal cortex. Serotonin and 5-hydroxy-L-tryptophan (5-HTP) induce a head-twitch response in wild-type (WT) mice that is a behavioral proxy for $5-\mathrm{HT}_{2 \mathrm{~A}} \mathrm{R}$ activation. The response in $\beta$-arrestin2 knock-out ( $\beta$ arr2-KO) mice is greatly attenuated until the doses are elevated, at which point, $\beta$ arr2-KO mice display a head-twitch response that can exceed that of WT mice. Direct administration of $N$-methyltryptamines also produces a greater response in $\beta$ arr2-KO mice. Moreover, the inhibition of $N$-methyltransferase blocks 5-HTP-induced head twitches in $\beta$ arr2-KO mice, indicating that $N$-methyltryptamines, rather than serotonin, primarily mediate this response. Biochemical studies demonstrate that serotonin stimulates Akt phosphorylation in the frontal cortex and in primary cortical neurons through the activation of a $\beta$-arrestin2/phosphoinositide 3-kinase/Src/Akt cascade, whereas $N$-methyltryptamines do not. Furthermore, disruption of any of the components of this cascade prevents 5-HTP-induced, but not $N$-methyltryptamine-induced, head twitches. We propose that there is a bifurcation of $5-\mathrm{HT}_{2 \mathrm{~A}} \mathrm{R}$ signaling that is neurotransmitter and $\beta$-arrestin 2 dependent. This demonstration of agonist-directed $5-\mathrm{HT}_{2 \mathrm{~A}} \mathrm{R}$ signaling in vivo may significantly impact drug discovery efforts for the treatment of disorders wherein hallucinations are part of the etiology, such as schizophrenia, or manifest as side effects of treatment, such as depression.
\end{abstract}

\section{Introduction}

The serotonin $2 \mathrm{~A}$ receptor $\left(5-\mathrm{HT}_{2 \mathrm{~A}} \mathrm{R}\right)$ is highly expressed on pyramidal neurons in the frontal cortex and has been implicated in several mental health disorders, including schizophrenia, anxiety, and depression (Jakab and Goldman-Rakic, 1998; Meltzer, 2002; Miner et al., 2003; Roth et al., 2004; Berg et al., 2008). The $5-\mathrm{HT}_{2 \mathrm{~A}} \mathrm{R}$ is also the target of serotonergic hallucinogenic drugs (Aghajanian and Marek, 1999; Nichols, 2004). Hallucinogens act at the $5-\mathrm{HT}_{2 \mathrm{~A}} \mathrm{R}$ to produce a distinct head-twitch response in rodents (Corne and Pickering, 1967) that is prevented by genetic ablation or pharmacological antagonism of the $5-\mathrm{HT}_{2 \mathrm{~A}} \mathrm{R}$ (Willins and Meltzer, 1997; González-Maeso et al., 2007; Keiser et al., 2009). Furthermore, systemic injections of 5-hydroxy-L-tryptophan (5-HTP), a metabolic precursor of serotonin, can elevate serotonin in the brain to levels that induce a robust headtwitch response in mice (Corne et al., 1963; Schmid et al.,

Received March 11, 2010; revised Aug. 5, 2010; accepted Aug. 9, 2010.

This work is funded by National Institute on Drug Abuse Grant DA025158 (L.M.B.). We acknowledge Dr. Robert J. Lefkowitz for providing the initial breeders for the $\beta$-arrestin2-K0 mouse line and for the $\mathrm{A} 2 \mathrm{CT}$ antibody and $\mathrm{Dr}$. Kenner Rice for providing the M100907 compound.

Correspondence should be addressed to Dr. Laura M. Bohn, 130 Scripps Way, \#2A2, Jupiter, FL 33458. E-mail: LBohn@scripps.edu.

D0I:10.1523/JNEUROSCI.1665-10.2010

Copyright $\odot 2010$ the authors $\quad$ 0270-6474/10/3013513-12\$15.00/0
2008). Moreover, the selective antagonist M100907 $[\mathrm{R}(+)-\alpha-$ (2,3-dimethoxyphenyl)-1-[2-(4-fluorophenylethyl)]-4-piperidinemethanol] [Chemical Abstract Services (CAS) registry number 139290-65-6], blocks this response, and 5-HTP-induced head twitches are lacking in $5-\mathrm{HT}_{2 \mathrm{~A}} \mathrm{R}$ knock-out (KO) mice (Schmid et al., 2008) (B. L. Roth, personal communication). The expression of $5-\mathrm{HT}_{2 \mathrm{~A}} \mathrm{Rs}$ in forebrain are likely mediating this response because the response to $5-\mathrm{HT}_{2 \mathrm{~A}} \mathrm{R}$ agonists can be rescued by expression of receptors in glutamatergic neurons in the frontal cortex of $5-\mathrm{HT}_{2 \mathrm{~A}} \mathrm{R}-\mathrm{KO}$ mice (González-Maeso et al., 2007).

The $5-\mathrm{HT}_{2 \mathrm{~A}} \mathrm{R}$ is a G-protein-coupled receptor (GPCR), and GPCRs can be activated by chemically distinct ligands to preferentially engage select signaling pathways, a characteristic referred to as "agonist-directed signaling" or "functional selectivity" (Kenakin, 1995; Kobilka and Deupi, 2007; Urban et al., 2007). $\beta$-Arrestins are intracellular scaffolding proteins that can either dampen or facilitate GPCR signaling and therefore may represent a key point at which receptor signaling may diverge in response to particular ligands (Luttrell and Lefkowitz, 2002; Lefkowitz et al., 2006; DeWire et al., 2007; Rajagopal et al., 2010). Diverse ligands to the $5-\mathrm{HT}_{2 \mathrm{~A}} \mathrm{R}$ have been shown to differentially activate downstream signaling cascades both in vitro and in vivo (Berg et al., 1998; Kurrasch-Orbaugh et al., 2003; González-Maeso et al., 2007; Schmid et al., 2008). We showed previously that serotonin 
Table 1. Numbers of mice used in behavioral studies

\begin{tabular}{|c|c|c|c|c|c|c|}
\hline \multirow{2}{*}{$\begin{array}{l}\text { Figure } \\
1 A, B\end{array}$} & \multirow{2}{*}{$\begin{array}{l}\text { Treatment in mice } \\
\text { 5-HTP }(\mathrm{mg} / \mathrm{kg}, \text { i.p. }) \pm \mathrm{M} 100\end{array}$} & \multicolumn{5}{|c|}{ Serotonergic dose and $n$ values } \\
\hline & & 100 & 150 & 200 & $M 100+200$ & \\
\hline & WT, $\beta$ arr2-KO & $n=13,8$ & $n=7,5$ & $n=8,7$ & $n=6,6$ & \\
\hline \multirow[t]{2}{*}{$1 C, D$} & 5-HT $(\mu$ g, i.c.v. $) \pm \mathrm{M} 100$ & 10 & 20 & 40 & $\mathrm{M} 100+40$ & \\
\hline & WT, $\beta$ arr2-KO & $n=4,5$ & $n=7,5$ & $n=5,6$ & $n=4,4$ & \\
\hline \multirow[t]{2}{*}{$1 E, F$} & Veh/Clor $( \pm \mathrm{M} 100)+5$-HTP & Veh +50 & Veh +100 & Clor +50 & Clor +100 & $\mathrm{Clor}+\mathrm{M} 100+100$ \\
\hline & WT, $\beta$ arr2-KO & $n=6,5$ & $n=6,5$ & $n=5,6$ & $n=9,8$ & $n=4,4$ \\
\hline \multirow[t]{2}{*}{$2 A, B$} & Veh/MTZ + 5-HTP & Veh +200 & $\mathrm{MTZ}+200$ & & & \\
\hline & WT, ßarr2-K0 & $n=4,5$ & $n=4,5$ & & & \\
\hline \multirow[t]{2}{*}{$3 A, B$} & $N-M e-5-H T$ ( $\mu$ g, i.c.v. $)$ & 10 & 20 & 40 & & \\
\hline & WT, $\beta$ arr2-KO & $n=4,4$ & $n=5,5$ & $n=4,4$ & & \\
\hline \multirow[t]{2}{*}{$3 C$} & Veh/M100 + N-Me-5-HT & Veh +20 & $M 100+20$ & & & \\
\hline & WT, $\beta$ arr2-KO & $n=4,4$ & $n=4,4$ & & & \\
\hline \multirow[t]{2}{*}{$3 D$} & Veh/MTZ + N-Me-5-HT & Veh +20 & $\mathrm{MTZ}+20$ & & & \\
\hline & WT & $n=5$ & $n=4$ & & & \\
\hline \multirow[t]{2}{*}{$3 E, F$} & 5-Me0-DMT (mg/kg, i.p.) & 5 & 10 & 15 & & \\
\hline & WT, $\beta$ arr2-KO & $n=9,10$ & $n=10,16$ & $n=5,5$ & & \\
\hline \multirow[t]{2}{*}{$3 G$} & Veh/M100 + 5-Me0-DMT & Veh +10 & $\mathrm{M} 100+10$ & & & \\
\hline & WT, $\beta$ arr2-KO & $n=5,9$ & $n=5,5$ & & & \\
\hline \multirow[t]{2}{*}{$3 H$} & Veh/MTZ + 5-Me0-DMT & Veh +10 & $\mathrm{MTZ}+10$ & & & \\
\hline & $\mathrm{C} 57 \mathrm{BL} / 6$ & $n=6$ & $n=4$ & & & \\
\hline \multirow[t]{2}{*}{$6 A, B$} & Veh, LY, PP2, AKTi + 5-HTP & Veh +200 & $L Y+200$ & $P P 2+200$ & $\mathrm{AKTi}+200$ & \\
\hline & $\mathrm{C} 57 \mathrm{BL} / 6$ & $n=10$ & $n=5$ & $n=5$ & $n=5$ & \\
\hline \multirow[t]{2}{*}{$6 C$} & Veh, AKTi + 5-Me0-DMT & 10 & AKTi +200 & & & \\
\hline & $\mathrm{C} 57 \mathrm{BL} / 6$ & $n=6$ & $n=4$ & & & \\
\hline \multirow[t]{2}{*}{$7 A, B$} & Veh, LY, PP2, AKTi + 5-HTP & 200 & $L Y+200$ & $P P 2+200$ & $\mathrm{AKTi}+200$ & \\
\hline & $\beta$ barr2-K0 & $n=7$ & $n=6$ & $n=6$ & $n=6$ & \\
\hline \multirow[t]{2}{*}{$8 A, B$} & Veh, AKTi, MTZ, AKTi + MTZ + 5-HTP & 200 & $\mathrm{MTZ}+200$ & AKTi +200 & $\mathrm{MTZ}+\mathrm{AKTi}+200$ & \\
\hline & WT & $n=11$ & $n=6$ & $n=5$ & $n=5$ & \\
\hline
\end{tabular}

Veh, Vehicle; 5-HT, serotonin; M100, M100907; Clor, clorgyline; N-Me-5-HT, N-methylserotonin; LY, LY294002. Serotonergic dosing routes: 5-HTP, mg/kg, i.p.; 5-HT and N-methylserotonin, $\mu$ g, i.c.v.; 5-Me0-DMT, mg/kg, i.p. For inhibitor and antagonist dosage information, see Materials and Methods.

and a synthetic hallucinogen, 2,5-dimethoxy-4-iodoamphetamine (DOI), can differentially activate the $5-\mathrm{HT}_{2 \mathrm{~A}} \mathrm{R}$ in cellular models as well as in vivo, wherein 5 -HTP requires $\beta$-arrestin 2 for the expression of the head-twitch response yet DOI does not (Schmid et al., 2008).

In the brain, serotonin is a substrate for $N$-methyltransferases, enzymes that act to convert serotonin to $N$-methyltryptamines; these metabolites possess psychoactive properties and can be hallucinogenic in humans (Axelrod, 1962; Glennon and Gessner, 1979; Shulgin and Shulgin, 1997; McBride, 2000). It has previously been very difficult to delineate the distinct neuropharmacological effects produced by serotonin and its psychoactive metabolites in vivo because many of the biogenic amines have higher affinities than serotonin at the $5-\mathrm{HT}_{2 \mathrm{~A}} \mathrm{R}$ (Glennon and Gessner, 1979; Blair et al., 2000). In this study, we demonstrate functional selectivity at the $5-\mathrm{HT}_{2 \mathrm{~A}} \mathrm{R}$ by serotonin and $\mathrm{N}$-methyltryptamines in vivo, as well as in the mouse frontal cortex and in primary cortical neurons in which we show that the actions of these neurotransmitters are functionally distinct.

\section{Materials and Methods}

Drugs. 5-HTP, serotonin (5-HT), $N$-methylserotonin oxalate salt (CAS registry number 1134-01-6), 5-methoxy- $N, N$-dimethyltryptamine (5-MeO-DMT) (CAS registry number 1019-45-0), and clorgyline were purchased from Sigma-Aldrich. MTZ [N,N'bis-(3-methyl-2-thiazolidinylidene)succinamide] (CAS registry number 65400-75-1) was purchased from Life Chemicals. LY294002 [2-(4-morpholinyl)-8phenyl-1(4H)-benzopyran-4-one], Akt inhibitor VIII (Akti; 1,3-dihydro-1( (4-(6-phenyl- $1 H$-imidazo[4,5-g] quinoxalin-7-yl)phenyl)methyl)-4piperidnyl)-2H-benzimidazol-2-one) and Src tyrosine kinase inhibitor (PP2; 4-amino-5-(4-chlorophenyl)-7-( $t$-butyl)-pyrazolo[3,4- $d]$ pyrimidine) were purchased from Cayman Chemical, Calbiochem, and Tocris Cookson, respectively. M100907 was provided by Dr. Kenner Rice (Na- tional Institute on Drug Abuse/National Institute on Alcohol Abuse and Alcoholism/National Institutes of Health, Bethesda, MD).

Primary antibodies. Total Akt (1:2000; pan C67E7), phospho-Akt (1: 1000; Thr308 C31E5E), and Src (1: 500; L4A1) antibodies were obtained from Cell Signaling Technology (Luan et al., 2009); anti-PSD-95 (1:500; K28/4) was purchased from University of California, Davis/National Institute of Neurological Disorders and Stroke/National Institute of Mental Health NeuroMab Facility (Davis, CA) (Fan et al., 2009); $\beta$-arrestin2 (1:2000; A2CT) antibody was provided by Dr. Robert Lefkowitz (Duke University, Howard Hughes Medical Institute, Durham, NC) (Bohn et al., 1999); the polyclonal antibody to the $\mathrm{N}$ terminus of the $5-\mathrm{HT}_{2 \mathrm{~A}} \mathrm{R}$ (1:500) was from Neuromics (Magalhaes et al., 2010); the c-Myc monoclonal antibody (1:500) was from Clontech/Takara Bio (Hu et al., 1995).

Mice. Subjects used in the experiments include male wild-type (WT) and $\beta$-arrestin 2 knock-out ( $\beta$ arr2-KO) mice derived via heterozygous breeding as well as male C57BL/6J mice (The Jackson Laboratory) between 2.5 and 9 months of age (Bohn et al., 1999; Schmid et al., 2008). Drugs administered intraperitoneally were prepared in $0.9 \%$ saline at a volume of $10 \mu \mathrm{l} / \mathrm{g}$ body weight; drugs administered intracerebroventricularly were prepared in $18 \Omega$ purified, distilled, sterile water and injected at a volume of $5 \mu \mathrm{l}, 2 \mathrm{~mm}$ caudal and $2 \mathrm{~mm}$ lateral from bregma at a depth of $3 \mathrm{~mm}$. Immediately after injection with agonist, mice were placed in individual Plexiglas boxes, and the number of head twitches were counted in $5 \mathrm{~min}$ increments for either 30 or $60 \mathrm{~min}$ (Schmid et al., 2008). In all cases, mice were used only once. All experiments were performed with the approval of the Institutional Animal Care and Use Committee of The Ohio State University or The Scripps Research Institute.

Behavioral experiments. The number of mice used in the experimental design is summarized in Table 1. For dose-response studies, WT and $\beta$ arr2-KO mice were treated with 5-HTP (100, 150, and 200 mg/kg, i.p), serotonin $(10,20$, and $40 \mu$ g, i.c.v.), $N$-methylserotonin (10, 20, and 40 $\mu$ g, i.c.v.), or 5-MeO-DMT $(5,10$, and $15 \mathrm{mg} / \mathrm{kg}$, i.p. $)$. To determine the contribution of monoamine oxidase A (MAO-A) metabolism to 5-HTPinduced head twitches, mice were pretreated (intraperitoneally) with 
either vehicle $(0.9 \%$ saline $)$ or clorgyline $(1 \mathrm{mg} / \mathrm{kg}) 60 \mathrm{~min}$ before treatment with 5-HTP (50 and $100 \mathrm{mg} / \mathrm{kg}$, i.p.). The $5-\mathrm{HT}_{2 \mathrm{~A}} \mathrm{R}$ antagonist M100907 (0.05 mg/kg, i.p.) was administered $10 \mathrm{~min}$ before 5-HTP (200 $\mathrm{mg} / \mathrm{kg}$, i.p.) or 5-HT ( $40 \mu$ g, i.c.v.) in Figure 1, $B$ and $D$, or 50 min after treatment with clorgyline $(1 \mathrm{mg} / \mathrm{kg}$, i.p. $)$ and $10 \mathrm{~min}$ before treatment with 5-HTP $(100 \mathrm{mg} / \mathrm{kg}$, i.p.) in Figure $1 F$. In Figure 3, M100907 was administered 10 min before treatment with $N$-methylserotonin $(20 \mu \mathrm{g}$, i.c.v.) or 5-MeO-DMT ( $10 \mathrm{mg} / \mathrm{kg}$, i.p.). The $\mathrm{M} 100907$ vehicle was $0.02 \%$ Tween 80 in water. The $N$-methyltransferase inhibitor MTZ (125 ng, i.c.v. $)$ or vehicle $\left(\mathrm{dH}_{2} \mathrm{O}\right.$ for studies in Figs. 2, 3 and in 1\% DMSO for studies in Fig. 8) was injected 10 min before treatment with 5-HTP (200 $\mathrm{mg} / \mathrm{kg}$, i.p.), $N$-methylserotonin $(20 \mu$ g, i.c.v. $)$, or 5-MeO-DMT (10 mg/ kg, i.p.). Vehicle (1\% DMSO), LY294002 (125 ng, i.c.v.), PP2 (300 ng, i.c.v.), or AKTi ( $55 \mathrm{ng}$, i.c.v.) was injected $10 \mathrm{~min}$ before treatment with 5 -HTP (200 mg/kg, i.p.). For the studies detailed in Figure 8, WT mice were pretreated with vehicle ( $1 \%$ DMSO), AKTi ( 55 ng, i.c.v.), MTZ ( 125 ng, i.c.v.), or both ATKi and MTZ for 10 min before treatment with 5 -HTP $(200 \mathrm{mg} / \mathrm{kg}$, i.p.). Dosing of the inhibitors was based on the literature (clorgyline: Tadano et al., 1989; MTZ: Mandel et al., 1978, Rokach et al., 1980; LY294002: Beaulieu et al., 2005; PP2: Narita et al., 2006; AKTi: Xu et al., 2008).

Biochemistry. Signaling in the mouse frontal cortex was determined after treatment of both WT and $\beta$ arr2-KO mice with vehicle $(0.9 \%$ saline, $n=23$ per genotype), 5 -HTP ( $100 \mathrm{mg} / \mathrm{kg}$, i.p., $n=16$ per genotype), or $5-\mathrm{MeO}-\mathrm{DMT}(10 \mathrm{mg} / \mathrm{kg}$, i.p., $n=5 \mathrm{WT}$ and $6 \beta$ arr2-KO). Mice were killed by cervical dislocation, and tissue was frozen immediately in liquid nitrogen. Tissue was homogenized by polytronic tissue grinder, followed by glass-on-glass dounce homogenization and then solubilized overnight at $4^{\circ} \mathrm{C}$ in immunoprecipitation lysis buffer $(20 \mathrm{~mm} \mathrm{NaF}, 10 \%$ glycerol, 50 mM Tris, $150 \mathrm{~mm} \mathrm{NaCl}, 0.5 \%$ NP-40, 1 mm PMSF, and 1 mM EDTA) containing a Mini EDTA-free protease inhibitor cocktail tablet (Roche Diagnostics) (Luan et al., 2009). Protein levels were determined by a protein assay kit compatible with detergent-based buffers (Bio-Rad) and 25-30 $\mu$ g of protein per lane were resolved on 10\% Bis-Tris gels (Invitrogen). Proteins were transferred to polyvinylidene fluoride membranes (Millipore Corporation) and immunoblotted for total-Akt or phosphoAkt. Chemiluminescence was detected using a Kodak 2000R imaging system (Eastman Kodak), and fluorescence was detected using an Odyssey Infrared imaging system (LI-COR Biosciences). Blots were quantified using NIH ImageJ analysis software. For each sample, phospho-Akt levels were normalized to corresponding total-Akt levels, and fold stimulation was determined by normalizing to the average vehicle levels for each experiment.

The 5- $\mathrm{HT}_{2 \mathrm{~A}} \mathrm{R}$ was immunoprecipitated from equivalent aliquots of remaining lysates by overnight incubation with a polyclonal rabbit antibody against the $\mathrm{N}$ terminus of the $5-\mathrm{HT}_{2 \mathrm{~A}} \mathrm{R}(1: 133$; Neuromics $)$ at $4^{\circ} \mathrm{C}$; complexes were immobilized on Protein A Sepharose 4 Fast Flow (GE Healthcare) beads for $3 \mathrm{~h}$ at room temperature. Beads were washed three times in lysis buffer, and proteins were eluted by heating in SDS sample buffer containing $5 \% \beta$-mercaptoethanol at $55^{\circ} \mathrm{C}$ for $20 \mathrm{~min}$. Immunoblot analysis was performed as described above, and representative Western blots are shown (vehicle, $n=11-24 \mathrm{WT}$ and 19-24 $\beta$ arr2-KO; 5-HTP, $n=4-18 \mathrm{WT}$ and 13-18 $\beta$ arr2-KO; 5-MeO-DMT, $n=5-7 \mathrm{WT}$ and 6-7 $\beta$ arr2-KO). Any alterations to enhance brightness or contrast were applied to the entire gel image. For quantification of the immunoprecipitation studies, the protein levels were first normalized to their corresponding $5-\mathrm{HT}_{2 \mathrm{~A}} \mathrm{R}$ immunoblots, and then drug treatment was normalized to vehicle-treated controls.

Primary neuronal cultures were generated from postnatal day 1 mouse neonates obtained from homozygous breeding of $\beta$ arr2-KO or WT mice (Askwith et al., 2004; Schmid et al., 2008). Frontal cortex was removed and digested in Leibovitz's L-15 (Invitrogen) solution containing $0.025 \%$ bovine serum albumin and $0.0375 \%$ papain for $15 \mathrm{~min}$ at $37^{\circ} \mathrm{C}$ with $95 \%$ oxygen $/ 5 \%$ carbon dioxide gently agitating the media. Tissue was washed in complete Neurobasal-A media (with $2 \%$ B-27 serum supplement, 0.5 $\mathrm{mm}$ L-glutamine, $1.675 \mu \mathrm{g} / \mathrm{L}$ sodium selenite, $2.5 \mathrm{mg} / \mathrm{L}$ insulin, 1.375 $\mathrm{mg} / \mathrm{L}$ transferring, and $50 \mu \mathrm{g} / \mathrm{ml}$ gentamycin; Invitrogen). A single-cell suspension was generated by triturating the tissue with glass pipettes of decreasing diameter. Neurons were then plated in Neurobasal-A media in 12-well dishes (one neonate $=$ two wells) coated with poly-L-lysine (Sigma-Aldrich).

Activation of Akt in neuronal cultures was determined on the fifth day after plating. Unless stated otherwise, neurons were incubated in serum-free MEM (Invitrogen) for $1 \mathrm{~h}$ before a $10 \mathrm{~min}$ drug treatment with $1 \mu \mathrm{M}$ agonist. For each assay, the number of wells of neurons treated over at least four separate experiments is provided. For agonist-induced Akt studies, neurons were treated with "agonist vehicle" ( $2 \mu \mathrm{M}$ ascorbate in water; $n=56 \mathrm{WT}$ and $35 \beta \mathrm{arr} 2-\mathrm{KO})$ or serotonin $(n=35 \mathrm{WT}$ and $23 \beta$ arr2-KO), $N$-methylserotonin $(n=19$ WT and $12 \beta$ arr2-KO), or 5-MeO-DMT ( $n=13 \mathrm{WT}$ and $12 \beta$ arr2KO). For Figure 5B, WT neurons were pretreated with M100907 (10 nM) (Johnson-Farley et al., 2005) or M100907 vehicle $(0.0001 \%$ DMSO) during the last 15 min of the serum starvation and before agonist stimulation. Neurons were then treated with either agonist vehicle or serotonin ( $n=8$ for each of the 4 conditions). For time course studies, neurons were lysed $0,1,3,5,10,20$, and $30 \mathrm{~min}$ after treatment with serotonin ( $n=4-8$ WT and 4-6 $\beta$ arr2-KO), $N$-methylserotonin ( $n=3-6$ per genotype), or 5-MeO-DMT ( $n=4-6$ per genotype). A concentration curve was completed for serotonin stimulation of Akt, wherein WT neurons were treated with agonist vehicle or 0.001-10 $\mu \mathrm{M}$ serotonin ( $n=8$ per dose) (data not shown). To compare basal phospho-Akt to total-Akt ratios between genotypes, WT and $\beta$ arr2-KO neurons were plated concurrently and lysed after treatment with agonist vehicle ( $n=9$ per genotype) (data not shown). For Figure $5 E$, inhibitor vehicle (0.1\% DMSO) or $1 \mu \mathrm{M} \mathrm{LY} 294002$ or PP2 was added to the serum-free media during the $1 \mathrm{~h}$ incubation. Neurons were then treated with either agonist vehicle or serotonin (Gingerich and Krukoff, 2008) (inhibitor vehicle + agonist vehicle, $n=$ 17; LY294002 + agonist vehicle, $n=9$; PP2 + agonist vehicle, $n=10$; inhibitor vehicle + serotonin, $n=19$; LY294002 + serotonin, $n=10$; PP2 + serotonin, $n=11$ ).

Rescue of serotonin-mediated Akt phosphorylation was accomplished by transfecting $\beta$ arr2-KO neurons with $4 \mu \mathrm{g}$ of $\mathrm{N}$-terminal Myc-tagged $\beta$-arrestin2 or empty vector (pcDNA3.1) via the calcium phosphate method (Jiang et al., 2004) (Clontech/BD Bioscience). After incubation in the DNA/calcium phosphate suspension for $2 \mathrm{~h}$ at $37^{\circ} \mathrm{C}$, neurons were washed twice with complete Neurobasal-A medium. Forty-eight hours after transfection, neurons were treated with either agonist vehicle or serotonin ( $n=9$ for each condition).

After treatment with agonist, primary neurons were washed once in PBS, and lysates were prepared in lysis buffer (20 mu Tris, $150 \mathrm{~mm} \mathrm{NaCl}$, 2 mм EDTA, 0.1\% SDS, 1\% NP-40, 0.25\% deoxycholate, 1 mm sodium orthovanadate, $1 \mathrm{~mm}$ PMSF, $1 \mathrm{~mm} \mathrm{NaF}$, and protease inhibitors) (Groer et al., 2007; Schmid et al., 2008). Lysates were prepared and Western blots were performed as described above to assess phospho-Akt and total-Akt levels. For $\beta$-arrestin2-rescue experiments, immunoblots were also probed with c-Myc antibody to confirm transfection. For each sample, phospho-Akt levels were normalized to corresponding total-Akt levels, and fold stimulation was determined by normalizing to the average vehicle levels for each experiment (or untreated controls for time course experiments).

Statistical analysis. Two-way ANOVA was used to examine group differences in head-twitch responses, comparing two main effects (such as genotype and dose); three-way ANOVA was used to compare three main effects, such as pretreatment, genotype, and dose. Post hoc comparisons between the total number of twitches between drug doses or across genotypes, as well as comparisons of the biochemical data were completed with a Student's unpaired, two-tailed $t$ test. All statistics were conducted with a confidence interval of $95 \%$ and were performed using GraphPad Prism 5.0 software (GraphPad Software) with the exception of the threeway ANOVAs, which were performed using PASW/SSPS 18.0 software (IBM). Three-way ANOVAs were followed by two-way ANOVA to further examine main effects within groups if visualization prompted the hypothesis that effects may differ within the groups. The use of three-way and one-way ANOVAs are noted in the text; otherwise, the analyses represent two-way ANOVA. Unless stated otherwise, Student's $t$ tests are presented in the figure legends. 


\section{Results}

\section{High doses of serotonin induce head twitches in}

Barr2-KO mice

Previously, we showed that mice lacking $\beta$-arrestin2 do not display a head-twitch response to a moderate dose of 5-HTP (100 $\mathrm{mg} / \mathrm{kg}$, i.p.) (Fig. $1 B$ ), suggesting that serotonin requires $\beta$-arrestin 2 to mediate this effect (Schmid et al., 2008). However, as the dose of 5-HTP increases, the number of twitches observed in both the WT and the $\beta$ arr2-KO mice also increases (Fig. $1 B$ : for genotype, $F_{(1,42)}=7.99, p=0.0072$; for dose, $F_{(2,42)}=15.30$, $p<0.0001)$. In effect, when the dose of 5-HTP is doubled, the response in the $\beta$ arr2-KO mice approaches that observed in WT mice (Fig. $1 A$ : for genotype, $F_{(1,156)}=8.15, p=0.0049$; for time, $\left.F_{(11,156)}=7.15, p<0.0001\right)$, indicating that high doses of 5-HTP can ultimately induce a head-twitch response in mice lacking $\beta$-arrestin2.

To ensure that this response was not attributable to unanticipated differences in the conversion of 5-HTP to serotonin in the Barr2-KO animals, mice were also treated directly with serotonin. After intracerebroventricular injection, lower doses of serotonin produce robust head twitches in WT mice that greatly exceed those observed in $\beta$ arr2-KO mice (Fig. $1 D$ : interaction genotype $\times$ dose, $\left.F_{(2,22)}=9.27, p=0.0012\right)$, which seems to be in agreement with the previous observations. Again, when the dose is escalated, the $\beta$ arr2-KO mice display more twitches than their WT littermates (Fig. 1C: for genotype, $F_{(1,54)}=16.61, p=0.0002$; for time, $\left.F_{(5,54)}=17.62, p<0.0001\right)$. Importantly, the effects of the highest doses of 5-HTP and serotonin were blocked by pretreatment with the 5- $\mathrm{HT}_{2 \mathrm{~A}} \mathrm{R}$ antagonist M100907 (Fig. $1 \mathrm{~B}$ : effect of M100907, $F_{(3,23)}=8.37, p=0.0006$, one-way ANOVA; Fig. $1 D$ : effect of M100907, $F_{(3,15)}=16.42, p<0.0001$, one-way ANOVA), demonstrating that these actions are indeed mediated via the $5-\mathrm{HT}_{2 \mathrm{~A}} \mathrm{R}$. Therefore, a question arises as to whether the deletion of $\beta$-arrestin 2 simply shifts the relative potency of serotonin at the $5-\mathrm{HT}_{2 \mathrm{~A}} \mathrm{R}$ or if serotonin really requires $\beta$-arrestin2 for signaling, as initially proposed (Schmid et al., 2008).

To further explore this question, we asked whether serotonin metabolites might contribute to the behavioral response. When serotonin levels are elevated, the neurotransmitter is primarily metabolized by MAO-A into 5-hydroxyindoleacetic acid (5-HIAA). However, serotonin can also be metabolized by $N$-methyltransferases into $N$-methyltryptamines, including $N$-methylserotonin, $N, N$-dimethylserotonin (bufotenine), and indirectly into dimethyltryptamine (Axelrod, 1962; Saavedra and Axelrod, 1972; Rosengarten and Friedhoff, 1976; Crooks et al., 1979). Whereas 5-HIAA is psychoactively inert, $N$-methyltryptamines are active neurotransmitters at the $5-\mathrm{HT}_{2 \mathrm{~A}} \mathrm{R}$ and have been reported to induce hallucinations in humans when taken directly (Glennon and Gessner, 1979; Shulgin and Shulgin, 1997; McBride, 2000). To determine whether the metabolism of serotonin could affect the number of head twitches observed in the WT and $\beta$ arr2-KO mice, the MAO-A inhibitor clorgyline was administered before low and moderate doses of 5-HTP treatment. As anticipated, inhibition of MAO-A shifts the dose-response curve leftward such that $\beta$ arr2-KO mice now respond to doses of 5-HTP that are ineffective when given alone (Fig. 1E: three-way ANOVA, multivariate analysis for the main effect of time, $F_{(11,14)}=4.87, p=0.003$; two-way ANOVA for $\mathrm{WT}$, interaction of pretreatment $\times$ time, $F_{(11,156)}=2.89, p=0.0017$; Barr2-KO, interaction of pretreatment $\times$ time, $F_{(11,132)}=2.18$, $p=0.019$; vehicle pretreatment, interaction of genotype $\times$ time, $F_{(11,108)}=6.98, p<0.0001$; clorgyline pretreatment, genotype,

\section{A 5 -HTP}

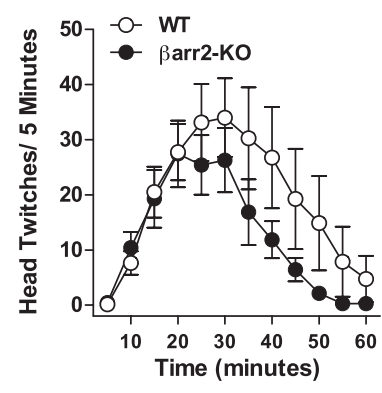

C Serotonin

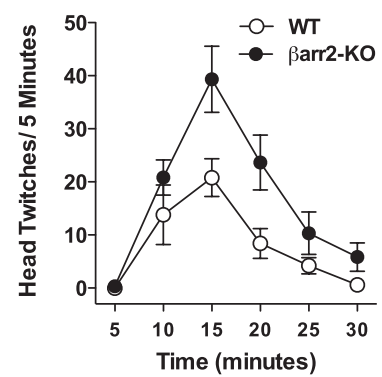

\section{E $5-\mathrm{HTP}+$}

WT: $-O-$ Veh $-\square-$ Clorgyline Barr2-KO: $\rightarrow$ Veh $\rightarrow-$ Clorgyline

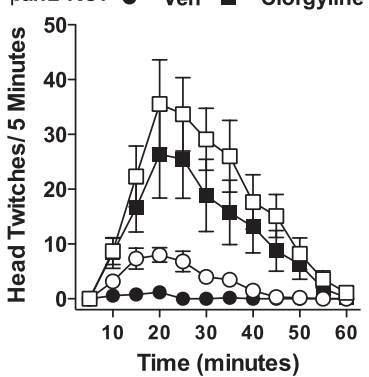

B

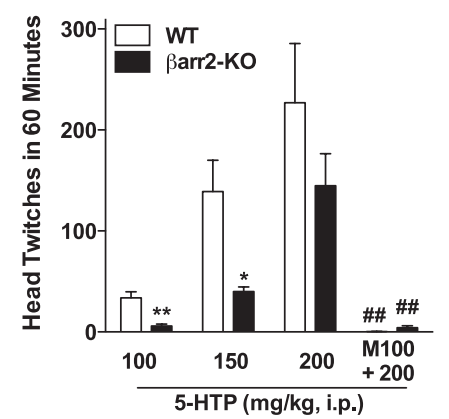

D

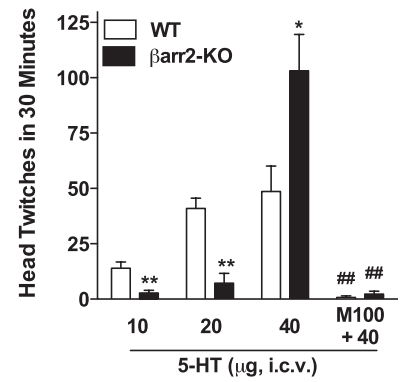

$\mathbf{F}$

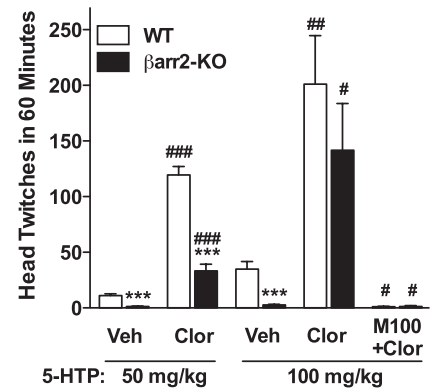

Figure 1. High doses of serotonin and 5-HTP can induce a head-twitch response in the Barr2-K0 mice. A-D, 5-HTP and serotonin induce a head-twitch response in WT and $\beta$ arr2-KO mice. Time course of 5-HTP (200 mg/kg, i.p.)-induced head-twitch response $(\boldsymbol{A})$ and 5 -HTP dose-response curves in WT and $\beta$ arr2-K0 mice and blockade of 5 -HTP-induced $(200 \mathrm{mg} / \mathrm{kg})$ responses ( $\boldsymbol{B}$ ) after a $10 \mathrm{~min}$ pretreatment with M100907 (M100; $0.05 \mathrm{mg} / \mathrm{kg}$, i.p.). WT versus Barr2-KO within dose: ${ }^{*} p<0.05$; ${ }^{* *} p<0.001$; within genotype: $200 \mathrm{mg} / \mathrm{kg} 5$-HTP versus $\mathrm{M} 100+200 \mathrm{mg} / \mathrm{kg} 5$-HTP, ${ }^{\# \#} p<0.001$. Time course of 5 -HT ( $40 \mu \mathrm{g}$, i.c.v.)-induced headtwitch response $(\boldsymbol{C})$ and serotonin dose-response curves in WT and $\beta$ arr2-KO mice and blockade of 5-HT-induced (40 $\mu$ g, i.c.v.) responses (D) after a 10 min pretreatment with M100907 $\left(0.05 \mathrm{mg} / \mathrm{kg}\right.$, i.p.). WT versus $\beta$ arr2-K0 at the same dose: ${ }^{*} p<0.05$; ${ }^{* *} p<0.001$; within genotype: $40 \mu \mathrm{g}$ of 5 -HT versus M100 + $40 \mu \mathrm{g}$ of $5-\mathrm{HT}:{ }^{\# \#} p<0.001 . E, F$, Inhibition of MAO-A enhances 5-HTP potency in both genotypes. Time course of 5-HTP ( $100 \mathrm{mg} / \mathrm{kg}$, i.p.)-induced head-twitch responses after a $1 \mathrm{~h}$ pretreatment with clorgyline (Clor; $1 \mathrm{mg} / \mathrm{kg}$, i.p.) or clorgyline vehicle (Veh; $0.9 \%$ saline, i.p.) ( $\boldsymbol{E}$ ) and the sum of twitches induced over the 60 min observation period at two doses of $5-$ HTP ( 50 and $100 \mathrm{mg} / \mathrm{kg}$, i.p.) in WT and $\beta$ arr2-K0 mice and blockade of clorgyline-enhanced 5 -HTP-induced ( $100 \mathrm{mg} / \mathrm{kg}$ ) responses after a $10 \mathrm{~min}$ pretreatment with M100907 $\left(0.05 \mathrm{mg} / \mathrm{kg}, \mathrm{i}\right.$..p.) $(\boldsymbol{F})$. WT versus $\beta$ arr2-K0 at the same dose: ${ }^{* * *} p<0.0001$. Vehicle pretreatment versus clorgyline pretreatment within genotype: ${ }_{p}<0.05$, ${ }^{\# \#} p<0.001$, ${ }_{\# \# \#} p<0.0001$; within genotype: clorgyline $+100 \mathrm{mg} / \mathrm{kg} 5$-HTP versus M100 + clorgyline + $100 \mathrm{mg} / \mathrm{kg} 5$-HTP: $\# p<0.05$. Mean \pm SEM are shown.

$F_{(1,180)}=6.48, p=0.0118$; Fig. $1 F$ : three-way ANOVA, for dose, $F_{(1,42)}=6.07, p=0.0180$; for pretreatment, $F_{(1,42)}=26.00, p<$ 0.001 ; for genotype, $\left.F_{(1,42)}=4.59, p=0.0380\right)$. Again, these effects are mediated through activation of the $5-\mathrm{HT}_{2 \mathrm{~A}} \mathrm{R}$ as the 
A 5-HTP +

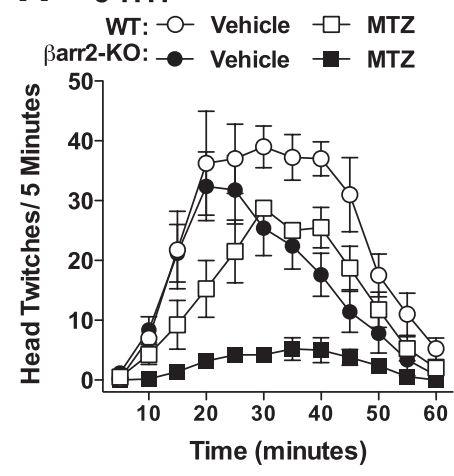

B

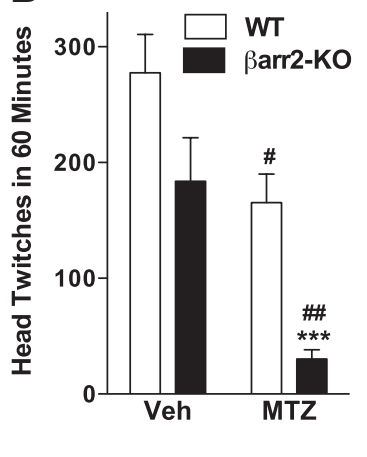

Figure 2. An N-methyltransferase inhibitor eliminates 5-HTP-induced head twitches in Barr2-KO mice. Pretreatment with an N-methyltransferase inhibitor, MTZ, blocks 5-HTPinduced head-twitch response in the $\beta$ arr2-KO mice and attenuates the response in WT mice. Time course analysis of head twitches induced by $200 \mathrm{mg} / \mathrm{kg} 5$-HTP (intraperitoneally) (A) and the total number of twitches observed over $60 \mathrm{~min}$ after a $10 \mathrm{~min}$ pretreatment with MTZ (125 ng, i.c.v.) or vehicle (5 $\mu \mathrm{l}$ of $\mathrm{dH}_{2} 0$, i.c.v.) (B). WT versus $\beta$ arr2-K0 with the same treatment: ${ }^{* * *} p<0.001$. Vehicle pretreatment versus MTZ pretreatment within genotype: ${ }^{*} p<0.05$, ${ }^{\# \#} p<0.01$. Mean \pm SEM are shown.

enhanced 5-HTP responses in both WT and $\beta$ arr2-KO mice are completely blocked by the $5-\mathrm{HT}_{2 \mathrm{~A}} \mathrm{R}$ antagonist (Fig. $1 \mathrm{~F}$ : effect of $\mathrm{M} 100907$ on $100 \mathrm{mg} / \mathrm{kg}$ clorgyline treatment, $F_{(3,21)}=5.21, p=$ 0.0076 , one-way ANOVA). Because clorgyline blocks the primary metabolic pathway for serotonin degradation, the increase in head twitches observed in the clorgyline pretreated $\beta$ arr2-KO mice may reflect an increase in $N$-methyltryptamine synthesis resulting from high levels of serotonin.

\section{Inhibitors of $N$-methyltransferase prevent the head-twitch response in $\beta$ arr2-KO mice}

High doses of 5-HTP promote high levels of serotonin in brain and may thereby facilitate $\mathrm{N}$-methyltransferase metabolism of serotonin to $N$-methyltryptamines (Axelrod, 1962). To determine the role of $N$-methyltryptamines in mediating the headtwitch response, we attempted to suppress $N$-methyltryptamine synthesis using an $\mathrm{N}$-methyltransferase inhibitor, MTZ before injection with a dose of 5 -HTP $(200 \mathrm{mg} / \mathrm{kg})$, which induces the greatest number of head twitches in the $\beta$ arr2-KO mice (Fig. $1 A, B)$ (Borchardt and Wu, 1976; Domino, 1976; Mandel et al., 1978; Rokach et al., 1980). The $N$-methyltransferase inhibitor decreases the number of 5-HTP-induced head twitches in both WT and $\beta$ arr2-KO mice, although the inhibitory effect is more pronounced in the $\beta$ arr2-KO mice (Fig. $2 A$ : three-way ANOVA for interactions of genotype $\times$ time, $F_{(11,4)}=5.99, p=0.0492$; two-way ANOVA for WT, pretreatment, $\mathrm{F}_{(1,72)}=34.84, p<$ 0.0001 ; time, $F_{(11,72)}=12.11, p<0.001$; for $\beta$ arr2-KO, interaction of pretreatment $\times$ time, $F_{(11,96)}=6.51, p<0.0001$; for vehicle pretreatment, genotype, $F_{(1,84)}=22.30, p<0.0001$; time, $F_{(11,84)}=18.18, p<0.0001 ;$ MTZ pretreatment, interaction of genotype $\times$ time, $F_{(11,84)}=6.48, p<0.0001$; Fig. $2 B$ : for genotype, $F_{(1,14)}=16.25, p=0.0012$; for pretreatment, $F_{(1,14)}=21.95$, $p=0.0004)$. These findings suggest that the head-twitch response induced in the $\beta$ arr $2-\mathrm{KO}$ mice may predominantly be attributed to the actions of the $\mathrm{N}$-methyltryptamines at the $5-\mathrm{HT}_{2 \mathrm{~A}} \mathrm{R}$ rather than those of serotonin per se.

\section{$\mathrm{N}$-methyltryptamine-induced head-twitch responses}

The actions of $\mathrm{N}$-methyltryptamines at the $5-\mathrm{HT}_{2 \mathrm{~A}} \mathrm{R}$ were directly evaluated in vivo using the endogenous metabolite $N$-methy- lserotonin, as well as a psychoactive yet hydrolysis-resistant dimethyltryptamine, 5-MeO-DMT. Direct intracerebroventricular injection of increasing doses of $\mathrm{N}$-methylserotonin induces a greater number of head twitches in the $\beta$ arr2-KO mice than their WT littermates, a response similar to that observed for the highest dose of serotonin tested (Fig. 3A: for genotype, $F_{(1,48)}=5.23, p=0.0002$; for time, $F_{(5,48)}=14.74, p<0.0001$; Fig. $3 B$ : interaction genotype $\times$ dose, $\left.F_{(2,20)}=6.45, p=0.0069\right)$. $N$-Methylserotonin induces head twitches through activation of the $5-\mathrm{HT}_{2 \mathrm{~A}} \mathrm{R}$ as the antagonist M100907 significantly inhibits the response in both genotypes (Fig. $3 C$ : interaction genotype $\times$ pretreatment, $F_{(1,12)}=6.60, p=$ 0.0246). Importantly, inhibition of $N$-methyltransferase by MTZ has no effect on $N$-methylserotonin-induced head twitches in WT mice, arguing against a nonspecific blockade of the behavior by the enzyme inhibitor (Fig. 3D: for pretreatment, $p>0.05$ ).

A similar response profile is observed after systemic treatment with 5-MeO-DMT wherein the $\beta$ arr2-KO mice display an enhanced head-twitch response compared with their WT littermates (Fig. 3E: for genotype, $F_{(1,144)}=32.70, p<0.0001$; for time, $F_{(5,144)}=54.67, p<0.0001$; Fig. 3F: interaction genotype $\times$ dose, $\left.F_{(2,49)}=3.79, p=0.0294\right)$. In addition, $5-\mathrm{HT}_{2 \mathrm{~A}} \mathrm{R}$ blockade with M100907 abrogates 5-MeO-DMT-induced head twitches in both genotypes (Fig. 3G: interaction genotype $\times$ pretreatment, $\left.F_{(1,20)}=5.85, p=0.0253\right)$, whereas MTZ pretreatment has no effect on 5-MeO-DMT-induced responses in normal mice (Fig. $3 \mathrm{H}$ : for pretreatment, $p>0.05)$. These findings suggest that $N$-methyltryptamines do not require $\beta$-arrestin2 to produce the head-twitch response in vivo and that $\beta$-arrestin 2 may play a negative regulatory role in this cascade because the mice consistently display greater responses to the $\mathrm{N}$-methyltryptamines when the protein is deleted.

\section{Phosphorylation of Akt in the frontal cortex}

The findings presented thus far suggest that the behavioral response to serotonin in the $\beta$ arr2-KO mice may be fundamentally different from that observed in the WT mice. To elucidate the signaling mechanisms underlying the differences in the head-twitch response between the two genotypes, the effects of serotonin on the $5-\mathrm{HT}_{2 \mathrm{~A}} \mathrm{R}$ were evaluated at the biochemical level. Therefore, we assessed agonist-induced activation of the serine-threonine kinase Akt in WT and $\beta$ arr2-KO frontal cortex after treatment with 5-HTP and 5-MeO-DMT. To attempt to exclude the contribution of the metabolites after the 5-HTP treatment, we used the dose of 5 -HTP $(100 \mathrm{mg} / \mathrm{kg}$, i.p. $)$ that only produced a head-twitch response in the WT mice, presuming that the head twitches observed in the $\beta$ arr2-KO mice at higher doses are indicative of the presence of serotonin metabolites. The dose of 5-MeO-DMT (10 $\mathrm{mg} / \mathrm{kg}$, i.p.) was chosen because it induces the greatest number of head twitches in both genotypes and therefore should elicit the most robust activation of the receptor signaling cascade. Treatment of WT mice with 5-HTP induces phosphorylation of Akt at threonine 308 (Fig. $4 A$ : WT, vehicle vs serotonin, $p=0.0018$, Student's $t$ test). However, Akt is not activated in the frontal cortex of $\beta$ arr2-KO mice after 5-HTP treatment ( $\beta$ arr2-KO, vehicle vs 5 -HTP, $p>0.05$, Student's $t$ test). Treatment with 5-MeO-DMT does not induce Akt phosphorylation in either genotype (vehicle vs $5-\mathrm{MeO}-\mathrm{DMT}, p>0.05$, Student's $t$ test). Importantly, comparison of vehicle-treated animals reveals no differences in Akt phosphorylation levels between genotypes, suggesting that the lack of serotonin-induced Akt stimulation in the $\beta$ arr2-KO mice is not attributable to an elevated basal state of Akt activation in the frontal cortex (data not shown). Together, these findings suggest that serotonin and 5-Meo-DMT differ in 
A N-Me-5-HT

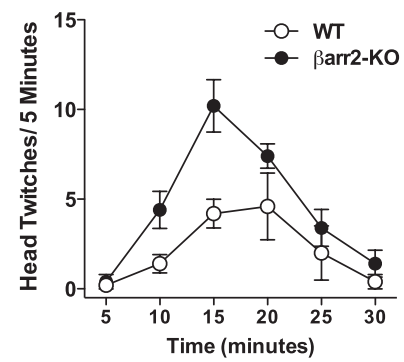

E 5-MeO-DMT

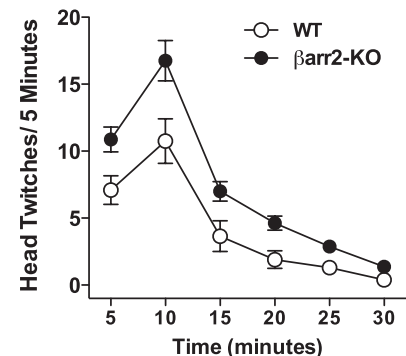

B N-Me-5-HT

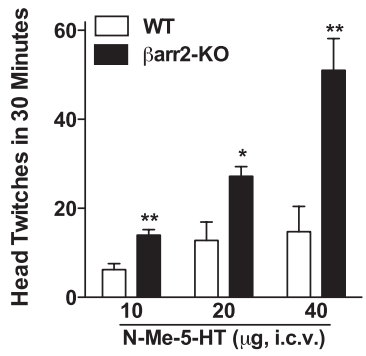

F 5-MeO-DMT

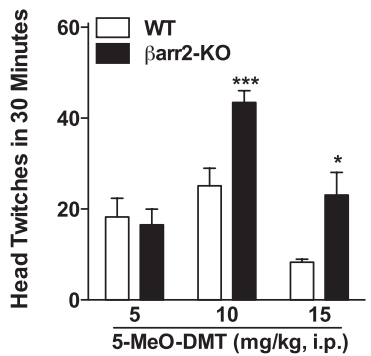

C $\mathrm{M} 100+\mathrm{N}-\mathrm{Me}-5-\mathrm{HT}$

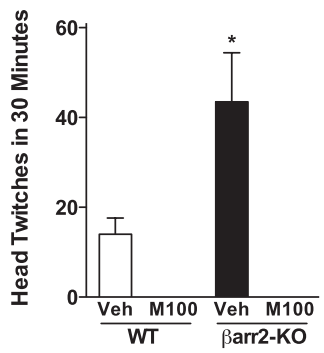

$\mathrm{G}_{\text {M100 + 5-MeO-DMT }}$

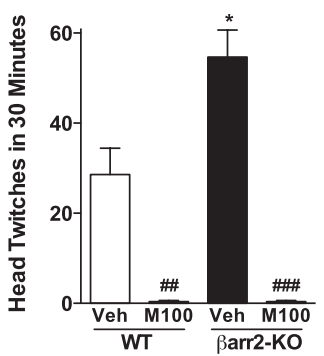

D MTZ + N-Me-5-HT

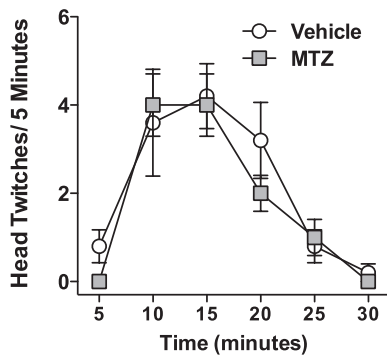

H MTZ + 5-MeO-DMT

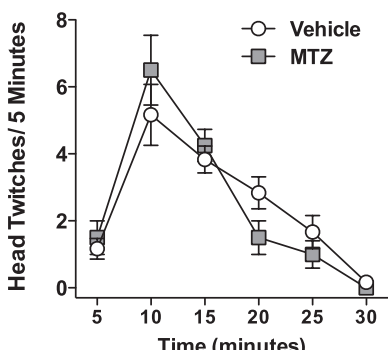

Figure 3. $\mathrm{N}$-Methyltryptamines induce more head twitches in $\beta$ arr2-KO mice than their WT littermates. $\beta$ arr2-KO mice treated with either $\mathrm{N}$-methylserotonin (N-Me-5-HT) (A-D) or 5-Me0-DMT ( $\boldsymbol{E}-\boldsymbol{H})$ display significantly more head twitches than WT mice. Time course of head twitches induced by $N$-methylserotonin $(20 \mu$, i.c.v. $)(\boldsymbol{A})$ and dose-response curve for the total number of head twitches observed over $30 \mathrm{~min}(\boldsymbol{B})$. WT versus $\beta$ arr2-K0: ${ }^{*} p<0.05,{ }^{* *} p<0.01$. C, Pretreatment (10 min) with the 5-HT ${ }_{2 A} \mathrm{R}$ antagonist M100907 (M100; 0.05 $\mathrm{mg} / \mathrm{kg}$, i.p.), but not vehicle $(0.02 \%$ Tween 80$)$, blocks the $N$-methylserotonin $\left(20 \mu\right.$ g, i.c.v.)-induced head-twitch response in both genotypes. WT versus $\beta$ arr2-K0: ${ }^{*} p<0.05 ;$ values for M100907 treatment were $0 \pm 0$. D. Pretreatment $(10 \mathrm{~min})$ of WT mice with the $\mathrm{N}$-methyltransferase inhibitor MTZ $\left(125 \mathrm{ng}\right.$, i.c.v.) or vehicle $\left(5 \mu\right.$ of $\mathrm{dH}_{2} 0$, i.c.v.) has no effect on the $\mathrm{N}$-methylserotonin $(20 \mu \mathrm{g}$, i.c.v.)-induced head-twitch response. $\boldsymbol{E}, \boldsymbol{F}$, Time course of head twitches induced by 5-Me0-DMT (10 mg/kg, i.p.) (E) and dose-response curve for the total number of head twitches observed over $30 \mathrm{~min}(\boldsymbol{F})$. WT versus Barr2-KO: ${ }^{*} p<0.05,{ }^{* * *} p<0.001$. G, Pretreatment (10 min) with M100907 (0.05 mg/kg, i.p.), but not vehicle, blocks the 5-Me0-DMT (10 mg/kg, i.p.)-induced head-twitch response in both genotypes. WT versus $\beta$ arr2-K0: ${ }^{*} p<0.05$; vehicle versus M100 within genotype: ${ }^{\# \#} p<0.01$, ${ }^{\# \# \#} p<0.0001$. $\boldsymbol{H}$, Pretreatment $(10 \mathrm{~min})$ of $\mathrm{C} 57 \mathrm{BL} / 6 \mathrm{~J}$ mice with MTZ (125 $\mathrm{ng}$, i.c.v.) or vehicle $\left(5 \mu \mathrm{l} \mathrm{of} \mathrm{dH}_{2} 0\right.$, i.c.v.) has no effect on the 5-Me0-DMT-induced (10 mg/kg, i.p.) head-twitch response. Mean \pm SEM are shown.

\section{A Frontal Cortex}
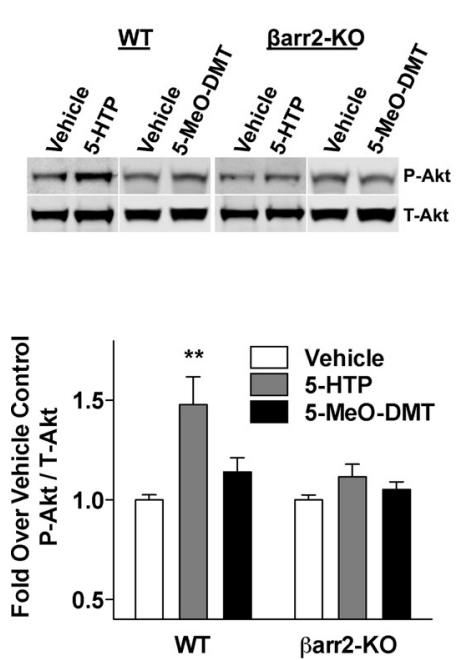

B
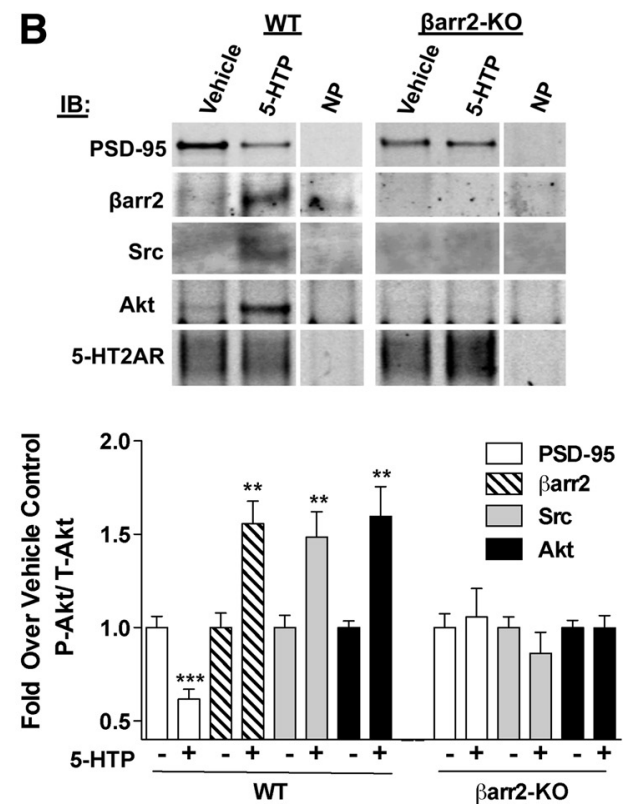
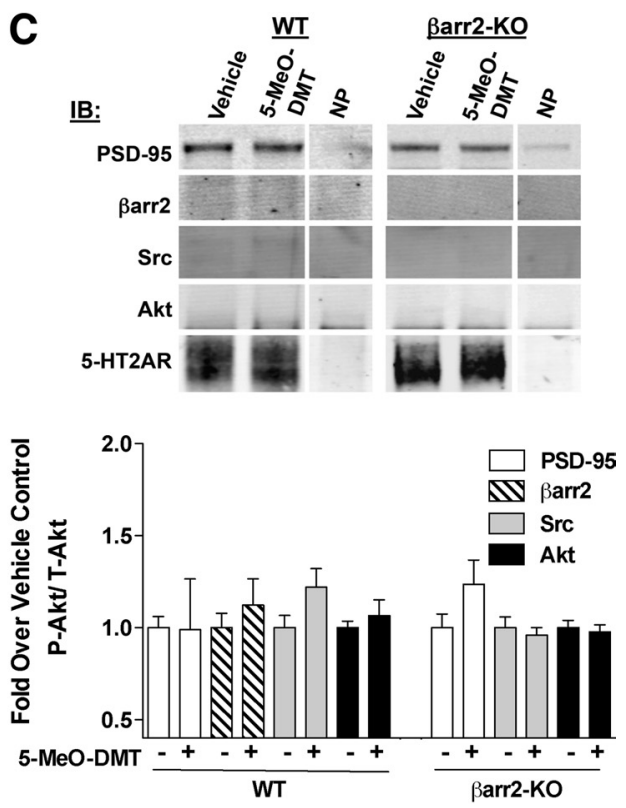

Figure 4. 5-HTP stimulates Akt phosphorylation and the association of $\beta$-arrestin2/Akt/Src complex with the $5-\mathrm{HT}_{2 \mathrm{~A}} \mathrm{R}$ in the frontal cortex. A, Treatment with 5 -HTP (100 mg/kg, i.p.) for $10 \mathrm{~min}$ induces Akt phosphorylation (P-Akt) in the frontal cortex of WT but not $\beta$ arr2-K0 mice. 5-Me0-DMT (10 mg/kg, i.p.) does not induce Akt phosphorylation in either genotype [total Akt (T-Akt)]. Vehicle versus 5-HTP: **p $<0.01$. B, 5-HT $2 \mathrm{~A}$ R immunoprecipitation reveals that 5-HTP treatment (100 mg/kg, i.p.) for 10 min decreases $5-\mathrm{HT}_{2 \mathrm{~A}} \mathrm{R}$ association with PSD-95 but increases 5 -HT $2 \mathrm{~A}$ associations with $\beta$-arrestin2, Src, and Akt. 5-HTP treatment has no effect on PSD-95, Src, or Akt coimmunoprecipitation with 5-HT ${ }_{2 A} \mathrm{R} \mathrm{in} \beta$ arr2-K0 mice. C, 5-Me0-DMT treatment (10 mg/kg, i.p. for $10 \mathrm{~min}$ ) does not displace PSD-95 from the immunoprecipitated 5- $\mathrm{HT}_{2 \mathrm{~A}} \mathrm{R}$, nor does it cause associations with $\beta$-arrestin2, Src, or Akt in either WT or $\beta$ arr2-K0 mice. A "no protein" control (NP; antibody + beads) is shown for each representative immunoblot. The mean \pm SEM of the densitometric analysis is shown. IB, Immunoblot. 
A Cortical Neurons

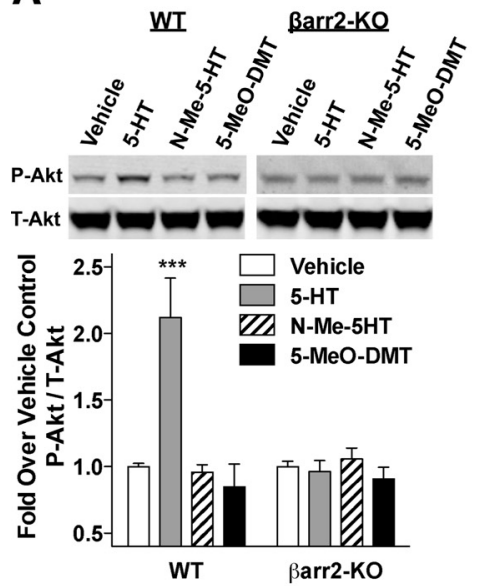

C
B WT
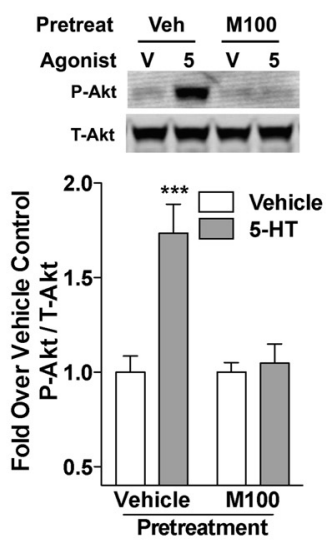

5-MeO-DMT
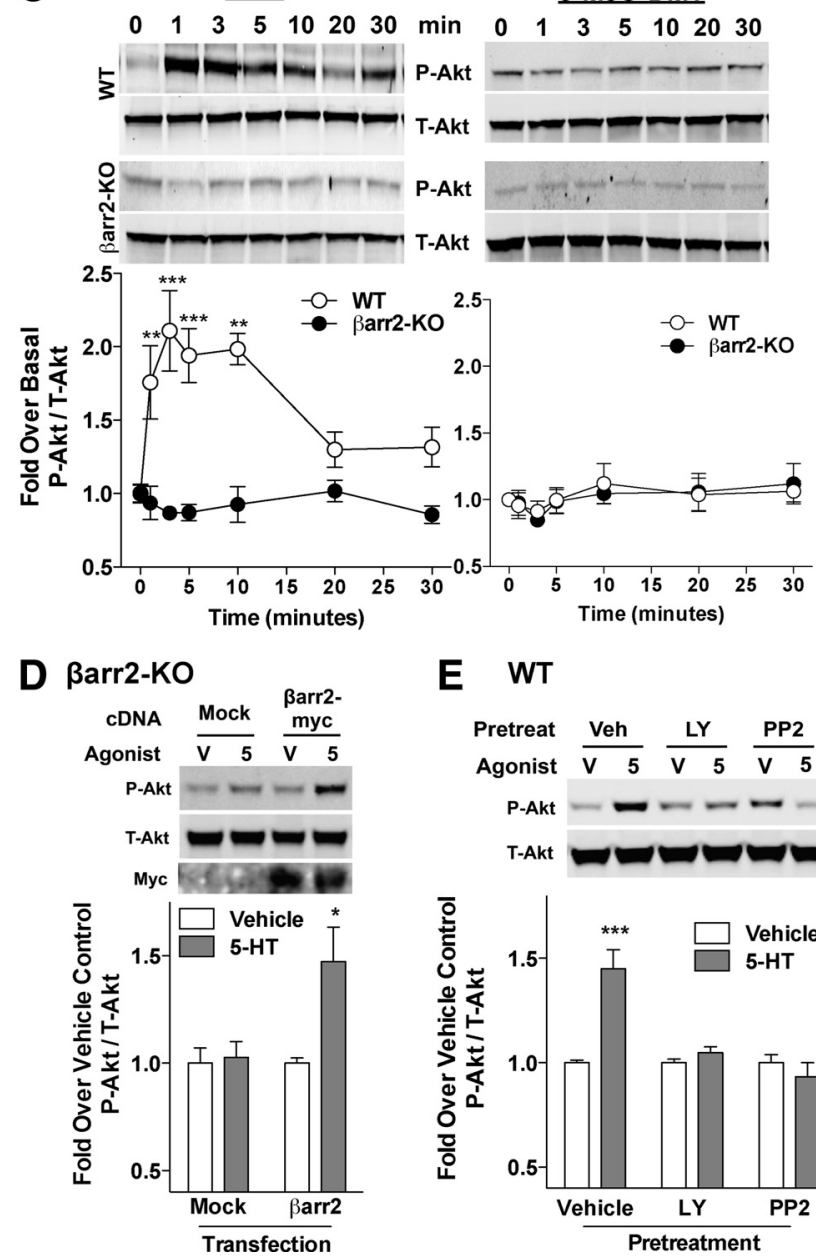

E WT
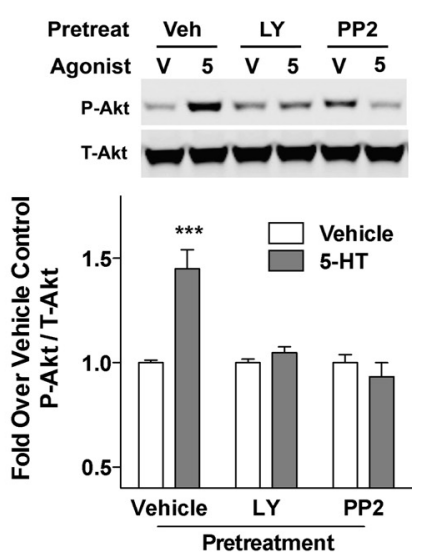

Figure 5. Serotonin stimulates Akt phosphorylation in mouse cortical neurons. $A, A 10 \mathrm{~min}$ 5-HT $(1 \mu \mathrm{M})$ treatment induces Akt phosphorylation in WT but not $\beta$ arr2-K0 primary cortical cultures. N-Methylserotonin (N-Me-5-HT) and 5-Me0-DMT do not stimulate Akt phosphorylation in either genotype. Vehicle versus 5-HT: ${ }^{* * *} p<0.001$. B, M100907 pretreatment (M100; $10 \mathrm{~nm}$ for $15 \mathrm{~min}$ ) inhibits Akt phosphorylation by serotonin ( $5 ; 1 \mu \mathrm{m}$ for $10 \mathrm{~min}$ ) compared with neurons that were pretreated with vehicle [M100 vehicle (Veh; Vehicle on abscissa) $=0.0001 \%$ DMSO; serotonin vehicle $(V$; Vehicle in the legend $)=2 \mu$ ascorbate] for the same time period. Vehicle versus $5-\mathrm{HT}:{ }^{* * *} p<0.001$, Bonferroni's post hoc analysis. C, Time course studies reveal Akt phosphorylation after treatment with $1 \mu \mathrm{m}$ serotonin (left) but not 5-Me0-DMT (right) in primary cortical cultures from WT mice, whereas $\beta$ arr2-KO neurons do not show Akt activation with either agonist. WT versus $\beta$ arr2-K0: ${ }^{* *} p<0.01,{ }^{* *} p<0.001$, Bonferroni's post hoc analysis. $\boldsymbol{D}$, Serotonin induces $(5 ; 1 \mu \mathrm{m}$ for $10 \mathrm{~min})$ Akt phosphorylation compared with vehicle their ability to activate Akt, such that serotonin requires $\beta$-arrestin2, whereas 5-MeO-DMT does not activate this kinase in frontal cortex.

Identification of a $\beta$-arrestin2-dependent $5-\mathrm{HT}_{2 \mathrm{~A}} \mathrm{R}$ signaling scaffold in frontal cortex

To directly implicate the $5-\mathrm{HT}_{2 \mathrm{~A}} \mathrm{R}$ in the agonist-induced signaling in vivo, the receptor was immunoprecipitated from the frontal cortex of both WT and $\beta$ arr2-KO mice after drug treatment. We then examined the contribution of $\beta$-arrestin 2 in assembling an Akt signaling scaffold by probing for proteins that associate with the receptor in response to 5 -HTP or 5-MeO-DMT. Interestingly, treatment of WT mice with 5-HTP at the same dose that stimulates Akt phosphorylation in the frontal cortex reveals a depletion of PSD-95 from the receptor complex and a recruitment of $\beta$-arrestin2, Src, and Akt (Fig. 4 B: WT, vehicle vs 5 -HTP: PSD-95, $p=0.0004 ; \beta$-arrestin $2, p=0.0024$; Src, $p=0.0017$; Akt, $p=0.0002$, Student's $t$ test). In contrast, in the absence of $\beta$-arrestin2, there is no depletion of PSD-95 or recruitment of Src or Akt to the receptor in response to 5-HTP ( $\beta$ arr2-KO, vehicle vs 5 -HTP, $p>0.05$, Student's $t$ test). In agreement with the studies presented in Figure 4A, treatment with 5-MeO-DMT does not lead to the recruitment of $\beta$-arrestin2, Src, or Akt to the $5-\mathrm{HT}_{2 \mathrm{~A}} \mathrm{R}$ in either genotype (Fig. 4C: vehicle vs 5-MeO-DMT, $p>0.05$, Student's $t$ test). These findings demonstrate that $\beta$-arrestin 2 is integral to mediating serotonin-induced assembly of a $5-\mathrm{HT}_{2 \mathrm{~A}} \mathrm{R} /$ Src/Akt signaling complex and that 5-MeO-DMT does not recruit this complex in the frontal cortex.

\section{Phosphorylation of Akt in primary cortical neurons}

To further characterize $5-\mathrm{HT}_{2 \mathrm{~A}} \mathrm{R}$-mediated serotonin-induced Akt activation, we used primary neuronal cultures generated from the frontal cortex of WT and $\beta$ arr2-KO neonates. Serotonin induces robust Akt phosphorylation in WT cortical neurons, which is maximal at $1 \mu \mathrm{M}$ (Fig. 5A: WT, vehicle vs serotonin, $p<$ 0.0001 , Student's $t$ test; dose-response not shown). However, $\mathrm{N}$-methylserotonin and 5-MeO-DMT do not activate the kinase (Fig. 5A: WT, vehicle vs $N$-methylserotonin or $5-\mathrm{MeO}-\mathrm{DMT}$, $p>0.05$, Student's $t$ test). In agreement with the observations made in the adult frontal cortex in Figure $4 A$, none of the agonists induce Akt phosphorylation in neuronal cultures derived from $\beta$ arr2-KO neonates (Fig. 5A: $\beta$ arr2-KO, vehicle vs agonist, $p>$ 0.05 , Student's $t$ test). Furthermore, pretreatment with M100907 prevents serotonin-induced Akt phosphorylation in WT neurons, demonstrating that the actions of serotonin are mediated via the $5-\mathrm{HT}_{2 \mathrm{~A}} \mathrm{R}$ (Fig. $5 B$ : vehicle vs serotonin: vehicle-pretreated, $p=0.0009$; M100907-pretreated, $p>0.05$, Student's $t$ test).

To be certain that the lack of Akt phosphorylation observed in the above studies was not attributable to temporal shifts in kinase activation profiles, we performed several time-dependent studies. Serotonin treatment over time reveals that Akt is phosphorylated within $1 \mathrm{~min}$ and peaks at 5-10 $\mathrm{min}$ in the WT neurons. The absence of Akt phosphorylation at all time points in the $\beta$ arr2-KO neurons demonstrates that there is not a $\beta$-arrestin2-

\section{$\leftarrow$}

( ; $2 \mu \mathrm{M}$ ascorbate) in $\beta$ arr2-K0 neurons transfected with Myc-tagged $\beta$-arrestin2 ( $\beta$ arr2myc), whereas those neurons transfected with empty vector (Mock) do not. Vehicle versus 5-HT: ${ }^{*} p<0.05$. E, Pretreatment (10 $\mu \mathrm{m}$ for $1 \mathrm{~h}$ ) with the PI3K inhibitor [LY294002 (LY)] or the Src inhibitor (PP2) blocks Akt phosphorylation induced by serotonin $(5 ; 1 \mu \mathrm{M}$ for $10 \mathrm{~min})$ in WT primary cortical neurons [inhibitor vehicle (Veh; Vehicle on abscissa) $=0.1 \%$ DMSO; serotonin vehicle (V; Vehicle in the legend) $=2 \mu \mathrm{m}$ ascorbate). Vehicle versus 5 -HT: ${ }^{* *} p<0.001$. Representative blots and densitometric analysis are provided. Mean \pm SEM are shown. 
dependent temporal shift in the activation profile, but rather that $\beta$-arrestin2 is essential for serotonin activation of Akt (Fig. $5 C$, left: for genotype, $F_{(1,69)}=55.47, p<0.0001$; for time, $F_{(6,69)}=$ $2.40, p=0.0367$ ). In addition, 5-MeO-DMT (Fig. 5C, right) and $\mathrm{N}$-methylserotonin (data not shown) fail to induce Akt phosphorylation in both genotypes at any time point tested, thereby demonstrating that the lack of Akt activation is not attributable to a temporal shift in activation profiles for these agonists $(p>0.05)$.

To determine whether the lack of serotonin-induced Akt phosphorylation in the Barr2-KO neurons is attributable to higher relative basal Akt activation levels, we directly compared phosphorylated Akt levels from vehicle-treated neurons of both genotypes run in parallel on the same gels. The data reveal that there are no differences between genotypes, suggesting that the inability of serotonin to stimulate Akt phosphorylation in the $\beta$ arr2-KO neurons is not attributable to increased basal phosphorylation of the kinase in these preparations (data not shown). In addition, treatment with fetal bovine serum stimulates Akt phosphorylation in $\beta$ arr2-KO neurons, demonstrating that Akt can be activated in this system (data not shown). Finally, transfection of Myc-tagged $\beta$-arrestin2 into $\beta$ arr2-KO neuronal cultures rescues serotonin-induced Akt phosphorylation, further demonstrating the necessity of $\beta$-arrestin2 in the activation of this pathway (Fig. $5 D$ : vehicle vs serotonin: mock transfected, $p>$ 0.05 ; Myc- $\beta$ arr2 transfected, $p=0.0100$, Student's $t$ test).

\section{Inhibition of serotonin-mediated Akt phosphorylation in neurons}

To evaluate the interplay of the signaling elements within the assembled complex, Akt phosphorylation was assessed after inhibiting individual components of the potential signaling cascade in primary cortical neuronal cultures. Phosphoinositide 3-kinase (PI3K) is an activator of Akt downstream of GPCRs, and pretreatment with a PI3K inhibitor (LY294002) prevents serotonininduced Akt phosphorylation in the WT neurons. The Src inhibitor PP2 also blocks Akt phosphorylation, further implicating these signaling elements in mediating the activation of Akt by serotonin (Fig. 5E: vehicle vs serotonin: vehicle-pretreated, $p<$ 0.0001 ; inhibitor-pretreated, $p>0.05$, Student's $t$ test).

\section{$\beta$-Arrestin2/PI3K/Src/Akt mediation of the head-twitch response}

To test whether the $\beta$-arrestin2/PI3K/Src/Akt complex contributes to the serotonin-mediated head-twitch response, we used kinase inhibitors to disrupt the function of the complex in vivo. Normal C57BL/6J mice were injected (intracerebroventricularly) with inhibitors of PI3K [LY294002 (Beaulieu et al., 2005)], Src [PP2 (Narita et al., 2006)], and Akt [AKTi (Xu et al., 2008)] before treatment with 5-HTP $(200 \mathrm{mg} / \mathrm{kg}$, i.p.). At this dose of 5-HTP, we would predict that both serotonin and $N$-methyltryptamine levels would be elevated. Because Akt only appears to play a role in the actions of serotonin, we might predict that the inhibitors of the Akt signaling cascade would inhibit the serotonin effects but maintain the $\mathrm{N}$-methyltryptamine effects. Accordingly, we find that each of the individual kinase inhibitors blocks $\sim 50 \%$ of the head-twitch response produced in the C57BL/6J mice (Fig. 6A: vehicle vs LY294002: for pretreatment, $F_{(1,156)}=38.52, p<0.0001$; for time, $F_{(11,156)}=5.51, p<0.0001 ; \mathrm{PP} 2$, for pretreatment, $F_{(1,156)}=$ 43.02, $p<0.0001$; for time, $F_{(11,156)}=6.17, p<0.0001 ; \mathrm{AKTi}$, for pretreatment, $F_{(1,156)}=35.94, p<0.0001$; for time, $F_{(11,156)}=6.49$, $p<0.0001$; Fig. $6 B: F_{(3,21)}=5.54, p=0.0058$, one-way ANOVA). Interestingly, the Akt inhibitor has no effect on the number of head
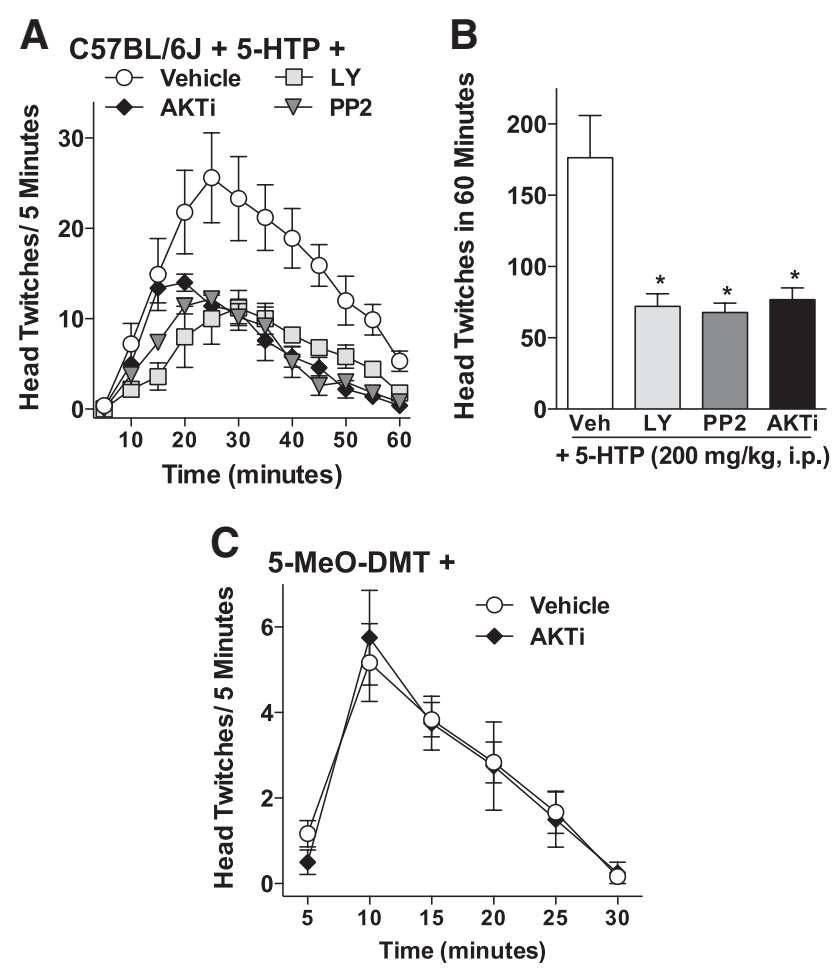

Figure 6. Inhibition of PI3K, SrC, or Akt attenuates 5-HTP-mediated but not $\mathrm{N}$-methyltryptamine-mediated head twitches in mice. $\boldsymbol{A}, \boldsymbol{B}$, Inhibitors of PI3K (LY294002), $\mathrm{Src}$ (PP2), or Akt (AKTi) attenuated 5-HTP-induced head twitches in normal mice. Time course of head-twitch responses $(\boldsymbol{A})$ and the total number of head twitches $(\boldsymbol{B})$ observed in $(57 \mathrm{BL} / 6 \mathrm{~J}$ mice that were pretreated for 10 min with either vehicle (Veh; $1 \% \mathrm{DMSO}$ in $\mathrm{dH}_{2} 0$, i.c.v.) or LY294002 (LY; 125 ng, i.c.v.), PP2 (300 ng, i.c.v.), or AKTi (55 ng, i.c.v.) before 5-HTP administration (200 mg/kg, i.p.). Vehicle versus inhibitor: ${ }^{*} p<0.05$. C, Pretreatment with AKTi $(55 \mathrm{ng}$, i.c.v. for $10 \mathrm{~min}$ ) has no effect on 5-Me0-DMT-induced $(10 \mathrm{mg} / \mathrm{kg}$, i.p.) head twitches in C57BL/6J mice compared with vehicle-pretreated ( $1 \%$ DMSO in $\mathrm{dH}_{2} 0$, i.c.v.) mice. Mean $\pm \mathrm{SEM}$ are shown.

twitches induced by 5-MeO-DMT (Fig. 6C: $p>0.05$ ). These data suggest that the head twitches induced by a high dose of 5-HTP can be partially blocked by inhibition of the Akt signaling cascade, suggesting that the remaining activity is either attributable to $5-\mathrm{HT}_{2 \mathrm{~A}} \mathrm{R}$ activity that is independent of this cascade or, alternatively, that metabolites of serotonin are signaling in an Akt-independent manner to mediate the head-twitch response.

In contrast, treatment of $\beta$ arr2-KO mice with PI3K, Src, and Akt inhibitors before treatment with 5-HTP $(200 \mathrm{mg} / \mathrm{kg}$, i.p.) does not lead to suppression of the head-twitch response (Fig. 7A: LY294002, PP2, and AKTi, for pretreatment, $p>0.05$; Fig. $7 B$ : $p>0.05$, one-way ANOVA). This may not be unanticipated because the behavioral data suggest that the highest dose of 5 -HTP produces the head-twitch response in the $\beta$ arr2-KO mice primarily as a result of the actions of the $N$-methyltryptamine metabolites (Fig. 2) and these metabolites do not activate Akt in vivo or in neuronal cultures (Figs. 4, 5). These findings further support a model wherein the head twitches that can be observed in the $\beta$ arr2-KO mice occur independent of a PI3K, Src, and Akt signaling mechanism.

\section{Separation of serotonin and $\mathrm{N}$-methyltryptamine responses in vivo}

Together, the biochemical and behavioral data suggest that the head-twitch response induced by high doses of 5-HTP or serotonin in WT mice may reflect the activity of both serotonin and 

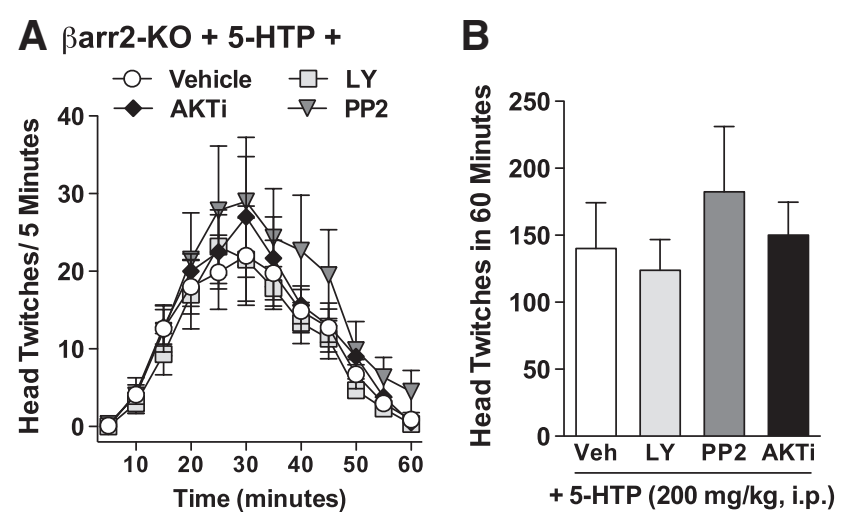

Figure 7. Inhibition of PI3K, Src, or Akt has no affect on 5-HTP-induced head twitches in Barr2-KO mice. Inhibitors of PI3K (LY294002), Src (PP2), or Akt (AKTi) have no effect on 5-HTPinduced head twitches in $\beta$ arr2-KO mice. Time course of head-twitch responses $(\boldsymbol{A})$ and the total number of head twitches $(\boldsymbol{B})$ observed in $\beta$ arr2-KO mice that were pretreated for $10 \mathrm{~min}$ with either vehicle (Veh; $1 \%$ DMSO in $\mathrm{dH}_{2}$ O, i.c.v.) or LY294002 (LY; $125 \mathrm{ng}$, i.c.v.), PP2 (300 ng, i.c.v.), or AKTi ( $55 \mathrm{ng}$, i.c.v.) before 5 -HTP administration $(200 \mathrm{mg} / \mathrm{kg}$, i.p.). Mean \pm SEM are shown.
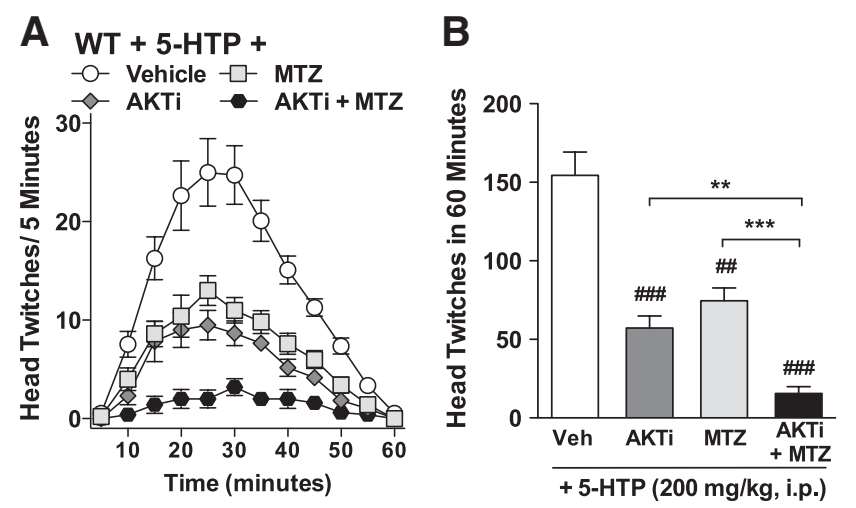

Figure 8. 5-HTP-induced head twitches in WT mice are blocked by combined inhibition of $\mathrm{N}$-methyltransferase and Akt. Pretreatment with the Akt inhibitor (AKTi) or the $\mathrm{N}$-methyItransferase inhibitor (MTZ) individually reduce 5-HTP-induced twitches in WT mice; coadministration of the inhibitors is additive. Time course $(\boldsymbol{A})$ and total numbers $(\boldsymbol{B})$ of head twitches observed in WT mice after 10 min pretreatment with either vehicle (Veh; $0.1 \%$ DMSO in $\mathrm{dH}_{2} 0$, i.c.V.), AKTi ( $55 \mathrm{ng}$, i.c.v.), or MTZ (125 ng, i.c.v.) alone, or AKTi and MTZ concurrently before 5-HTP administration (200 $\mathrm{mg} / \mathrm{kg}$, i.p.) Vehicle versus inhibitor: ${ }^{\# \#} p<0.01,{ }^{\# \# \#} p<0.001$. AKTi versus AKTi + MTZ: ${ }^{* *} p<$ 0.01; MTZ versus AKTi + MTZ: ${ }^{* * *} p<0.001$. Mean \pm SEM are shown.

$\mathrm{N}$-methyltryptamines. To directly test this hypothesis, WT mice were treated with the Akt inhibitor (to block serotonin-mediated signaling) and the $N$-methyltransferase inhibitor (to prevent $\mathrm{N}$-methyltryptamine synthesis) before treatment with a dose of 5 -HTP $(200 \mathrm{mg} / \mathrm{kg}$, i.p.) that produces the greatest response when given alone (Fig. $1 A$ ). Remarkably, this double blockade nearly abolishes the 5-HTP-induced head-twitch response in WT mice (Fig. 8: compared with vehicle: AKTi, for pretreatment, $F_{(1,180)}=96.55, p<0.0001$; for time, $F_{(11,180)}=19.77, p<$ 0.0001 ; MTZ, for pretreatment, $F_{(1,168)}=53.73, p<0.0001$; for time, $F_{(11,168)}=18.82, p<0.0001 ; \mathrm{AKTi}+\mathrm{MTZ}$, for pretreatment, $F_{(1,168)}=172.24, p<0.0001$; for time, $F_{(11,168)}=10.77$, $p<0.0001)$.

\section{Discussion}

In this study, we demonstrate functional selectivity at the $5-\mathrm{HT}_{2 \mathrm{~A}} \mathrm{R}$ whereby serotonin and $\mathrm{N}$-methyltryptamines differentially induce the head-twitch response in mice and promote differential signaling in mouse frontal cortex and in primary cortical neurons. We show that serotonin activates the formation of a receptor signaling complex that includes $\beta$-arrestin2, Src, and Akt and that blockade of any individual component, as well as PI3K, prevents the full expression of the head-twitch response, thus demonstrating the physiological relevance of this complex formation. Furthermore, we also show that, although $N$-methyltryptamines mediate the head-twitch response through activation of the $5-\mathrm{HT}_{2 \mathrm{~A}} \mathrm{R}$, the mechanism is independent of $\beta$-arrestin 2 and does not require Akt activation (summarized in Fig. 9). Together, these findings point to a signaling pathway that may represent a signature of the actions of serotonin at the $5-\mathrm{HT}_{2 \mathrm{~A}} \mathrm{R}$ in cortex that is distinct from those activated by $\mathrm{N}$-methyltryptamines.

The differences between these neurotransmitters, observed in both behavioral and biochemical responses, fit into the conceptual framework of functional selectivity, an idea based on the understanding that a ligand can selectively stabilize a receptor conformation, causing the receptor to preferentially interact with particular intracellular signaling components (Kenakin, 1995; Mailman, 2007; Urban et al., 2007; Violin and Lefkowitz, 2007; Rajagopal et al., 2010). Agonist-directed signaling at the $5-\mathrm{HT}_{2 \mathrm{~A}} \mathrm{R}$ has been demonstrated previously in vitro wherein certain agonists have been shown to preferentially stimulate different degrees of phospholipase $\mathrm{C}$ or phospholipase $\mathrm{A}_{2}$ activity (Berg et al., 1998; Kurrasch-Orbaugh et al., 2003; Moya et al., 2007). Moreover, functional selectivity at the $5-\mathrm{HT}_{2 \mathrm{~A}} \mathrm{R}$ has long been speculated in vivo, because not all agonists at the receptor induce hallucinations in humans (Pieri et al., 1978). Studies addressing differences between hallucinogenic and non-hallucinogenic agonists have shown that LSD (hallucinogen) and lisuride (nonhallucinogen) differ in their ability to induce the head-twitch response and activate distinct patterns of gene expression in the frontal cortex (González-Maeso et al., 2003, 2007). Our findings further support the physiological relevance of agonist-directed signaling at the $5-\mathrm{HT}_{2 \mathrm{~A}} \mathrm{R}$ in vivo, because two endogenous neurotransmitters (hallucinogenic $N$-methyltryptamines and nonhallucinogenic serotonin) differentially use $\beta$-arrestin 2 to signal and induce the head-twitch response.

The fact that functional selectivity can be observed between two endogenous neurotransmitters may have a significant impact on how modulation of $5-\mathrm{HT}_{2 \mathrm{~A}} \mathrm{R}$ activation is targeted from a drug discovery perspective. This may be particularly important for the treatment of depression wherein traditional therapies focus on elevating endogenous serotonin levels that can produce adverse side effects such as a "serotonin syndrome." This condition can be accompanied by hallucinations and is particularly problematic when selective serotonin reuptake inhibitors are taken with monoamine oxidase inhibitors (Insel et al., 1982; Sternbach, 1991; Boyer and Shannon, 2005) when serotonin, and presumably $\mathrm{N}$-methyltryptamine, levels would be greatly elevated. If we surmise that the actions of serotonin are beneficial as opposed to the actions of the $N$-methyltryptamines (which can be hallucinogenic), then, from a therapeutic perspective, it would be beneficial to directly mimic the actions of serotonin at the receptor. This would involve the identification of agonists that preferentially engage the $\beta$-arrestin 2 -dependent pathway as opposed to a G-protein-mediated, $\beta$-arrestin2-independent signaling pathway.

The divergence in neurotransmitter-directed 5- $\mathrm{HT}_{2 \mathrm{~A}} \mathrm{R}$ signaling may also have implications for the treatment of schizophrenia, because there has been a long-standing hypothesis that the hallucinations associated with this disease may be attributed to $N$-methyltryptamine actions (Kety, 1959; Snyder et al., 1974; 
Domino, 1976). Moreover, schizophrenic patients that experienced hallucinations as part of the pathology were found to have elevated $N$-methyltryptamine levels in urine, which may indicate higher endogenous levels of these amines (Bidder et al., 1974; Lipinski et al., 1974; Angrist et al., 1975; Takeda et al., 1995; Emanuele et al., 2010). Because both serotonin and the $N$-methyltryptamines produce the same behavior in mice (the head-twitch response), it is not clear whether the two agonists will promote the same physiological responses in humans or whether the $\mathrm{N}$-methyltryptamines contribute to the hallucinations experienced in schizophrenia. However, the endogenous neurotransmitter serotonin is not considered to be a hallucinogen, and the direct administration of $\mathrm{N}$-methyltryptamines can produce hallucinations, further supporting the idea that these two agonists likely have divergent signaling mechanisms in humans. Our studies in mice demonstrate a mechanistic divergence of these neurotransmitters and indicate that it may be possible to pharmacologically inhibit the actions of the $N$-methyltryptamines while simultaneously permitting signaling that mimics that promoted by serotonin.

The critical role scaffolding molecules play in neurotransmitter receptor signaling may become more apparent when these receptors are studied in neuronal systems. For example, the activation of $\mathrm{D}_{2}$ dopamine receptors leads to $\beta$-arrestin2-dependent inhibition of Akt by forming a $\mathrm{PP} 2 \mathrm{~A} / \mathrm{Akt} / \beta$-arrestin 2 complex, suggesting that $\beta$-arrestin 2 plays a facilitatory role toward deactivating Akt in this system (Beaulieu et al., 2005, 2008). However, interactions between Akt and Src are necessary for full activation of Akt in some systems (Chen et al., 2001; Jiang and Qiu, 2003), and our findings suggest that this $\beta$-arrestin2-facilitated interaction is of functional consequence for serotonin signaling at the $5-\mathrm{HT}_{2 \mathrm{~A}} \mathrm{R}$. In addition to $\beta$-arrestin2, the postsynaptic density scaffolding protein PSD-95 has also been shown to interact with the $5-\mathrm{HT}_{2 \mathrm{~A}} \mathrm{R}$ and to play an essential role in regulating signal transduction for hallucinogenic drugs at this receptor; PSD-95 promotes clustering of the 5- $\mathrm{HT}_{2 \mathrm{~A}} \mathrm{R}$ on the plasma membrane in HEK-293 cells (Xia et al., 2003 ) and is integral for the dendritic targeting of the receptor in cortical pyramidal neurons (Abbas et al., 2009). Our previous work demonstrates that the $5-\mathrm{HT}_{2 \mathrm{~A}} \mathrm{R}$ is more highly localized to the plasma membrane of cortical neurons in $\beta$ arr2-KO mice, although it is constitutively internalized in the WT neurons (Schmid et al., 2008). Our findings here show that, in the absence of $\beta$-arrestin2, PSD-95 is not displaced from the $5-\mathrm{HT}_{2 \mathrm{~A}} \mathrm{R}$ in response to 5-HTP (Fig. 4B). Altogether, the interplay between $\beta$-arrestin 2 and PSD-95 may determine whether the receptor is internalized or remains on the cell surface. Moreover, an attractive hypothesis is that $\beta$-arrestin2, in concert with PSD-95, represents a fulcrum in the ligand-directed signaling of this receptor in vivo.

The question remains as to how the $N$-methyltryptamines induce the head-twitch response. Because this effect is indepen- dent of $\beta$-arrestin2, it is likely that G-protein-dependent signaling mediates the effects of these metabolites. It is well established that the $5-\mathrm{HT}_{2 \mathrm{~A}} \mathrm{R}$ couples primarily to $\mathrm{G} \alpha_{\mathrm{q}}$ and can also couple to $\mathrm{G} \alpha_{\mathrm{i} / \mathrm{o}^{-}}$-and $\mathrm{G} \alpha_{12 / 13}$-proteins. Interestingly, the genetic deletion of $\mathrm{G} \alpha_{\mathrm{q}}$ decreases responsiveness to DOI-induced head twitches, suggesting that this G-protein plays an important role in mediating the effects of DOI in vivo (Garcia et al., 2007). Furthermore, DOI induces head twitches in the $\beta$ arr2-KO mice, suggesting that its effects are not mediated via a $\beta$-arrestin2-dependent pathway (Schmid et al., 2008). Together, these findings suggest that at least part of the $\beta$-arrestin2-independent head-twitch response may be mediated through a G-protein pathway.

Interestingly, an enhanced head-twitch response is observed in the $\beta$ arr2-KO mice after treatment with both 5-MeO-DMT and $N$-methylserotonin, suggesting that $\beta$-arrestin2 may play a negative regulatory role on $5-\mathrm{HT}_{2 \mathrm{~A}} \mathrm{R}$ function when activated by these agonists, a phenomenon observed for other GPCRs in vivo (Bohn et al., 1999; Breivogel et al., 2008; Deshpande et al., 2008; Schmid and Bohn, 2009). However, if $\beta$-arrestin 2 was negatively regulating the receptor, then one might expect to find $\beta$-arrestin2 coimmunoprecipitated with the $5-\mathrm{HT}_{2 \mathrm{~A}} \mathrm{R}$ after $5-\mathrm{MeO}-\mathrm{DMT}$ treatment. This does not occur (Fig. 4C), and it is not clear whether this lack of coimmunoprecipitation is a result of a lack of interaction or a difference in the agonist-induced nature of the interaction that renders the complex less stable during the immunoprecipitation process. Behaviorally, the $N$-methyltryptamines (either by direct administration or metabolically derived from high doses of serotonin) consistently induce more head twitches in the $\beta$ arr2-KO mice than in the WT mice, whereas lower doses 
of serotonin only induce twitches in the WT mice. Therefore, $\beta$-arrestin 2 appears to be both facilitating (for serotonin) and dampening (for $N$-methyltryptamines) a particular receptormediated response, wherein the agonist determines the regulatory role that $\beta$-arrestin 2 plays during interaction with the 5- $\mathrm{HT}_{2 \mathrm{~A}} \mathrm{R}$ (Fig. 9).

Our studies have focused primarily on the $5-\mathrm{HT}_{2 \mathrm{~A}} \mathrm{R}$ because this receptor has been most highly correlated with the agonistinduced display of the head-twitch response in mice, although other serotonin receptor subtypes, including the $5-\mathrm{HT}_{2 \mathrm{C}} \mathrm{R}$ and the $5-\mathrm{HT}_{1 \mathrm{~A}} \mathrm{R}$, can modulate the extent of this behavioral response (Arnt and Hyttel, 1989; Berendsen and Broekkamp, 1991; Schreiber et al., 1995; Canal et al., 2010). As with any pharmacological studies performed in vivo, drug effects may be influenced by actions at nontarget receptors, and the variations in the head-twitch response profiles observed between the agonists could reflect differential contributions of other serotonin receptors. Nevertheless, the immunoprecipitation studies reported herein, which use an N-terminal-directed antibody that does not detect the protein in the $5-\mathrm{HT}_{2 \mathrm{~A}} \mathrm{R}-\mathrm{KO}$ mice (Magalhaes et al., 2010), support the conclusion that the lack of Akt activation by serotonin in the $\beta$ arr2-KO mice is attributable to disruption of $5-\mathrm{HT}_{2 \mathrm{~A}} \mathrm{R}$ signaling.

Overall, these studies demonstrate that, although both serotonin and its metabolic products act at the $5-\mathrm{HT}_{2 \mathrm{~A}} \mathrm{R}$, the functionality of the receptor diverges in vivo at the level of the ligand-directed receptosome formation, which dictates signaling that underlies the display of the head-twitch response in mice. Future drug discovery efforts to identify serotonin mimetics should consider agonist-dependent signal bifurcation at $\beta$-arrestin 2 because this may have particular relevance to the development of antipsychotic and antidepressant therapies.

\section{References}

Abbas AI, Yadav PN, Yao WD, Arbuckle MI, Grant SG, Caron MG, Roth BL (2009) PSD-95 is essential for hallucinogen and atypical antipsychotic drug actions at serotonin receptors. J Neurosci 29:7124-7136.

Aghajanian GK, Marek GJ (1999) Serotonin and hallucinogens. Neuropsychopharmacology 21:16S-23S.

Angrist B, Thompson H, Shopsin B, Gershon S (1975) Clinical studies with dopamine-receptor stimulants. Psychopharmacologia 44:273-280.

Arnt J, Hyttel J (1989) Facilitation of 8-OHDPAT-induced forepaw treading of rats by the 5-HT2 agonist DOI. Eur J Pharmacol 161:45-51.

Askwith CC, Wemmie JA, Price MP, Rokhlina T, Welsh MJ (2004) Acidsensing ion channel 2 (ASIC2) modulates ASIC1 $\mathrm{H}+$-activated currents in hippocampal neurons. J Biol Chem 279:18296-18305.

Axelrod J (1962) The enzymatic N-methylation of serotonin and other amines. J Pharmacol Exp Ther 138:28-33.

Beaulieu JM, Sotnikova TD, Marion S, Lefkowitz RJ, Gainetdinov RR, Caron MG (2005) An Akt/beta-arrestin 2/PP2A signaling complex mediates dopaminergic neurotransmission and behavior. Cell 122:261-273.

Beaulieu JM, Marion S, Rodriguiz RM, Medvedev IO, Sotnikova TD, Ghisi V, Wetsel WC, Lefkowitz RJ, Gainetdinov RR, Caron MG (2008) A betaarrestin 2 signaling complex mediates lithium action on behavior. Cell 132:125-136.

Berendsen HH, Broekkamp CL (1991) Attenuation of 5-HT1A and 5-HT2 but not 5-HT1C receptor mediated behaviour in rats following chronic treatment with 5-HT receptor agonists, antagonists or anti-depressants. Psychopharmacology (Berl) 105:219-224.

Berg KA, Maayani S, Goldfarb J, Scaramellini C, Leff P, Clarke WP (1998) Effector pathway-dependent relative efficacy at serotonin type $2 \mathrm{~A}$ and $2 \mathrm{C}$ receptors: evidence for agonist-directed trafficking of receptor stimulus. Mol Pharmacol 54:94-104.

Berg KA, Harvey JA, Spampinato U, Clarke WP (2008) Physiological and therapeutic relevance of constitutive activity of 5-HT 2A and 5-HT 2C receptors for the treatment of depression. Prog Brain Res 172:287-305.

Bidder TG, Mandel LR, Ahn HS, VandenHeuvel WJ, Walker RW (1974)
Letter: blood and urinary dimethyltryptamine in acute psychotic disorders. Lancet 1:165.

Blair JB, Kurrasch-Orbaugh D, Marona-Lewicka D, Cumbay MG, Watts VJ, Barker EL, Nichols DE (2000) Effect of ring fluorination on the pharmacology of hallucinogenic tryptamines. J Med Chem 43:4701-4710.

Bohn LM, Lefkowitz RJ, Gainetdinov RR, Peppel K, Caron MG, Lin FT (1999) Enhanced morphine analgesia in mice lacking beta-arrestin 2. Science 286:2495-2498.

Borchardt RT, Wu YS (1976) Potential inhibitors of S-adenosylmethioninedependent methyltransferases. 5 . Role of the asymmetric sulfonium pole in the enzymatic binding of S-adenosyl-L-methionine. J Med Chem 19:1099-1103.

Boyer EW, Shannon M (2005) The serotonin syndrome. N Engl J Med 352:1112-1120.

Breivogel CS, Lambert JM, Gerfin S, Huffman JW, Razdan RK (2008) Sensitivity to delta9-tetrahydrocannabinol is selectively enhanced in betaarrestin2-/- mice. Behav Pharmacol 19:298-307.

Canal CE, Olaghere da Silva UB, Gresch PJ, Watt EE, Sanders-Bush E, Airey DC (2010) The serotonin 2C receptor potently modulates the headtwitch response in mice induced by a phenethylamine hallucinogen. Psychopharmacology (Berl) 209:163-174.

Chen R, Kim O, Yang J, Sato K, Eisenmann KM, McCarthy J, Chen H, Qiu Y (2001) Regulation of Akt/PKB activation by tyrosine phosphorylation. J Biol Chem 276:31858-31862.

Corne SJ, Pickering RW (1967) A possible correlation between druginduced hallucinations in man and a behavioural response in mice. Psychopharmacologia 11:65-78.

Corne SJ, Pickering RW, Warner BT (1963) A method for assessing the effects of drugs on the central actions of 5-hydroxytryptamine. Br J Pharmacol Chemother 20:106-120.

Crooks PA, Dreyer RN, Sulens CH, Gillis CN, Coward JK (1979) Determination of 5-hydroxytryptamine metabolites in isolated perfused rabbit lung by high-performance liquid chromatography. Anal Biochem 93:143-152.

Deshpande DA, Theriot BS, Penn RB, Walker JK (2008) Beta-arrestins specifically constrain beta2-adrenergic receptor signaling and function in airway smooth muscle. FASEB J 22:2134-2141.

DeWire SM, Ahn S, Lefkowitz RJ, Shenoy SK (2007) Beta-arrestins and cell signaling. Annu Rev Physiol 69:483-510.

Domino EF (1976) Search for new treatment approaches in schizophrenia: in vitro studies of potential $\mathrm{N}$-methyltransferase inhibitors. Arch Int Pharmacodyn Ther 221:75-86.

Emanuele E, Colombo R, Martinelli V, Brondino N, Marini M, Boso M, Barale F, Politi P (2010) Elevated urine levels of bufotenine in patients with autistic spectrum disorders and schizophrenia. Neuro Endocrinol Lett 31:117-121.

Fan J, Cowan CM, Zhang LY, Hayden MR, Raymond LA (2009) Interaction of postsynaptic density protein-95 with NMDA receptors influences excitotoxicity in the yeast artificial chromosome mouse model of Huntington's disease. J Neurosci 29:10928-10938.

Garcia EE, Smith RL, Sanders-Bush E (2007) Role of G(q) protein in behavioral effects of the hallucinogenic drug 1-(2,5-dimethoxy-4-iodophenyl)2-aminopropane. Neuropharmacology 52:1671-1677.

Gingerich S, Krukoff TL (2008) Activation of ERbeta increases levels of phosphorylated nNOS and NO production through a Src/PI3K/Aktdependent pathway in hypothalamic neurons. Neuropharmacology $55: 878-885$.

Glennon RA, Gessner PK (1979) Serotonin receptor binding affinities of tryptamine analogues. J Med Chem 22:428-432.

González-Maeso J, Yuen T, Ebersole BJ, Wurmbach E, Lira A, Zhou M, Weisstaub N, Hen R, Gingrich JA, Sealfon SC (2003) Transcriptome fingerprints distinguish hallucinogenic and nonhallucinogenic 5-hydroxytryptamine $2 \mathrm{~A}$ receptor agonist effects in mouse somatosensory cortex. J Neurosci 23:8836-8843.

González-Maeso J, Weisstaub NV, Zhou M, Chan P, Ivic L, Ang R, Lira A, Bradley-Moore M, Ge Y, Zhou Q, Sealfon SC, Gingrich JA (2007) Hallucinogens recruit specific cortical 5-HT(2A) receptor-mediated signaling pathways to affect behavior. Neuron 53:439-452.

Groer CE, Tidgewell K, Moyer RA, Harding WW, Rothman RB, Prisinzano TE, Bohn LM (2007) An opioid agonist that does not induce mu-opioid receptor-beta-arrestin interactions or receptor internalization. Mol Pharmacol 71:549-557.

Hu Q, Klippel A, Muslin AJ, Fantl WJ, Williams LT (1995) Ras-dependent 
induction of cellular responses by constitutively active phosphatidylinositol-3 kinase. Science 268:100-102.

Insel TR, Roy BF, Cohen RM, Murphy DL (1982) Possible development of the serotonin syndrome in man. Am J Psychiatry 139:954-955.

Jakab RL, Goldman-Rakic PS (1998) 5-Hydroxytryptamine2A serotonin receptors in the primate cerebral cortex: possible site of action of hallucinogenic and antipsychotic drugs in pyramidal cell apical dendrites. Proc Natl Acad Sci U S A 95:735-740.

Jiang M, Deng L, Chen G (2004) High $\mathrm{Ca}^{2+}$-phosphate transfection efficiency enables single neuron gene analysis. Gene Ther 11:1303-1311.

Jiang T, Qiu Y (2003) Interaction between Src and a C-terminal proline-rich motif of Akt is required for Akt activation. J Biol Chem 278:15789-15793.

Johnson-Farley NN, Kertesy SB, Dubyak GR, Cowen DS (2005) Enhanced activation of Akt and extracellular-regulated kinase pathways by simultaneous occupancy of Gq-coupled 5-HT2A receptors and Gs-coupled 5-HT7A receptors in PC12 cells. J Neurochem 92:72-82.

Keiser MJ, Setola V, Irwin JJ, Laggner C, Abbas AI, Hufeisen SJ, Jensen NH, Kuijer MB, Matos RC, Tran TB, Whaley R, Glennon RA, Hert J, Thomas KL, Edwards DD, Shoichet BK, Roth BL (2009) Predicting new molecular targets for known drugs. Nature 462:175-181.

Kenakin T (1995) Agonist-receptor efficacy. II. Agonist trafficking of receptor signals. Trends Pharmacol Sci 16:232-238.

Kety SS (1959) Biochemical theories of schizophrenia. I. Science 129: $1528-1532$.

Kobilka BK, Deupi X (2007) Conformational complexity of G-proteincoupled receptors. Trends Pharmacol Sci 28:397-406.

Kurrasch-Orbaugh DM, Parrish JC, Watts VJ, Nichols DE (2003) A complex signaling cascade links the serotonin $2 \mathrm{~A}$ receptor to phospholipase A2 activation: the involvement of MAP kinases. J Neurochem 86:980-991.

Lefkowitz RJ, Rajagopal K, Whalen EJ (2006) New roles for beta-arrestins in cell signaling: not just for seven-transmembrane receptors. Mol Cell 24:643-652.

Lipinski JF, Mandel LR, Ahn HS, Vanden Heuvel WJ, Walker RW (1974) Blood dimethyltryptamine concentrations in psychotic disorders. Biol Psychiatry 9:89-91.

Luan B, Zhao J, Wu H, Duan B, Shu G, Wang X, Li D, Jia W, Kang J, Pei G (2009) Deficiency of a beta-arrestin-2 signal complex contributes to insulin resistance. Nature 457:1146-1149.

Luttrell LM, Lefkowitz RJ (2002) The role of beta-arrestins in the termination and transduction of G-protein-coupled receptor signals. J Cell Sci 115:455-465.

Magalhaes AC, Holmes KD, Dale LB, Comps-Agrar L, Lee D, Yadav PN, Drysdale L, Poulter MO, Roth BL, Pin JP, Anisman H, Ferguson SS (2010) CRF receptor 1 regulates anxiety behavior via sensitization of 5-HT2 receptor signaling. Nat Neurosci 13:622-629.

Mailman RB (2007) GPCR functional selectivity has therapeutic impact. Trends Pharmacol Sci 28:390-396.

Mandel LR, Rokach J, Rooney CS, Cragoe EJ Jr (1978) Inhibition of dimethyltryptamine biosynthesis by $N, N^{\prime}$-bis-(3-methyl-2-thiazolidinylidene) succinamide (I) and 2-imino-3-methylthiazolidine (II). Mol Pharmacol 14:930-939.

McBride MC (2000) Bufotenine: toward an understanding of possible psychoactive mechanisms. J Psychoactive Drugs 32:321-331.

Meltzer HY (2002) Mechanism of action of atypical antipsychotic drugs. In: Neuropsychopharmacology: the fifth generation of progress (Davis KL, Charney D, Coyle JT, Nemeroff C, eds), pp 819-832. New York: Raven.

Miner LA, Backstrom JR, Sanders-Bush E, Sesack SR (2003) Ultrastructural localization of serotonin $2 \mathrm{~A}$ receptors in the middle layers of the rat prelimbic prefrontal cortex. Neuroscience 116:107-117.

Moya PR, Berg KA, Gutiérrez-Hernandez MA, Sáez-Briones P, Reyes-Parada M, Cassels BK, Clarke WP (2007) Functional selectivity of hallucinogenic phenethylamine and phenylisopropylamine derivatives at human 5-hydroxytryptamine (5-HT)2A and 5-HT2C receptors. J Pharmacol Exp Ther 321:1054-1061.
Narita M, Kato H, Kasukawa A, Narita M, Suzuki M, Takeuchi T, Suzuki T (2006) Role of Src family kinase in the rewarding effect and hyperlocomotion induced by morphine. Neuroreport 17:115-119.

Nichols DE (2004) Hallucinogens. Pharmacol Ther 101:131-181.

Pieri L, Keller HH, Burkard W, Da Prada M (1978) Effects of lisuride and LSD on cerebral monoamine systems and hallucinosis. Nature 272:278-280.

Rajagopal S, Rajagopal K, Lefkowitz RJ (2010) Teaching old receptors new tricks: biasing seven-transmembrane receptors. Nat Rev Drug Discov 9:373-386.

Rokach J, Girard Y, Hamel P, Reader G, Rooney CS, Mandel LR, Cragoe EJ Jr, Zacchei AG (1980) Inhibitors of indoleethylamineN-methyltransferase. Derivatives of 3-methyl-2-thiazolidinimine. In vitro, in vivo, and metabolic studies. J Med Chem 23:773-780.

Rosengarten H, Friedhoff AJ (1976) A review of recent studies of the biosynthesis and excretion of hallucinogens formed by methylation of neurotransmitters or related substances. Schizophr Bull 2:90-105.

Roth BL, Hanizavareh SM, Blum AE (2004) Serotonin receptors represent highly favorable molecular targets for cognitive enhancement in schizophrenia and other disorders. Psychopharmacology (Berl) 174:17-24.

Saavedra JM, Axelrod J (1972) Psychotomimetic N-methylated tryptamines: formation in brain in vivo and in vitro. Science 175:1365-1366.

Schmid CL, Bohn LM (2009) Physiological and pharmacological implications of beta-arrestin regulation. Pharmacol Ther 121:285-293.

Schmid CL, Raehal KM, Bohn LM (2008) Agonist-directed signaling of the serotonin $2 \mathrm{~A}$ receptor depends on beta-arrestin-2 interactions in vivo. Proc Natl Acad Sci U S A 105:1079-1084.

Schreiber R, Brocco M, Audinot V, Gobert A, Veiga S, Millan MJ (1995) (1-(2,5-dimethoxy-4 iodophenyl)-2-aminopropane)-induced headtwitches in the rat are mediated by 5 -hydroxytryptamine (5-HT) $2 \mathrm{~A}$ receptors: modulation by novel 5-HT2A/2C antagonists, D1 antagonists and 5-HT1A agonists. J Pharmacol Exp Ther 273:101-112.

Shulgin A, Shulgin A (1997) TiHKAL: the continuation. Berkeley, CA: Transform.

Snyder SH, Banerjee SP, Yamamura HI, Greenberg D (1974) Drugs, neurotransmitters, and schizophrenia. Science 184:1243-1253.

Sorensen SM, Kehne JH, Fadayel GM, Humphreys TM, Ketteler HJ, Sullivan CK, Taylor VL, Schmidt CJ (1993) Characterization of the 5-HT2 receptor antagonist MDL 100907 as a putative atypical antipsychotic: behavioral, electrophysiological and neurochemical studies. J Pharmacol Exp Ther 266:684-691.

Sternbach H (1991) The serotonin syndrome. Am J Psychiatry 148: 705-713.

Tadano T, Satoh S, Satoh N, Kisara K, Arai Y, Kim SK, Kinemuchi H (1989) Potentiation of para-hydroxyamphetamine-induced head-twitch response by inhibition of monoamine oxidase type A in the brain. J Pharmacol Exp Ther 250:254-260.

Takeda N, Ikeda R, Ohba K, Kondo M (1995) Bufotenine reconsidered as a diagnostic indicator of psychiatric disorders. Neuroreport 6:2378-2380.

Urban JD, Clarke WP, von Zastrow M, Nichols DE, Kobilka B, Weinstein H, Javitch JA, Roth BL, Christopoulos A, Sexton PM, Miller KJ, Spedding M, Mailman RB (2007) Functional selectivity and classical concepts of quantitative pharmacology. J Pharmacol Exp Ther 320:1-13.

Violin JD, Lefkowitz RJ (2007) Beta-arrestin-biased ligands at seventransmembrane receptors. Trends Pharmacol Sci 28:416-422.

Willins DL, Meltzer HY (1997) Direct injection of 5-HT2A receptor agonists into the medial prefrontal cortex produces a head-twitch response in rats. J Pharmacol Exp Ther 282:699-706.

Xia Z, Hufeisen SJ, Gray JA, Roth BL (2003) The PDZ-binding domain is essential for the dendritic targeting of 5-HT2A serotonin receptors in cortical pyramidal neurons in vitro. Neuroscience 122:907-920.

Xu X, Chua CC, Gao J, Chua KW, Wang H, Hamdy RC, Chua BH (2008) Neuroprotective effect of humanin on cerebral ischemia/reperfusion injury is mediated by a PI3K/Akt pathway. Brain Res 1227:12-18. 